\title{
SUPREMO RELATOR \\ Processo decisório e mudanças na composição do STF nos governos FHC e Lula*
}

\section{Fabiana Luci de Oliveira}

\section{A importância política do Supremo e o processo decisório}

O Supremo Tribunal Federal é um ator cada vez mais central no sistema político brasileiro, sendo muito influente na formulação e na implementação de políticas públicas.

O protagonismo político do Poder Judiciário como um todo, e do STF, especificamente, fica mais evidente a partir da extensa cobertura midiática na medida em que os tribunais vão sendo chamados a decidir sobre questôes proeminentes na agenda nacional de políticas públicas. Nos últimos anos o STF foi chamado a decidir sobre temas

* Esse artigo é resultado da pesquisa de Pós-Doutorado realizado no Departamento de Ciência Política da USP, com o suporte financeiro da Fapesp.

Artigo recebido em 29/11/2010

Aprovado em 26/03/2012 como privatização de empresas; a contribuição previdenciária dos servidores públicos inativos; a pesquisa com células-tronco; o aborto de anencéfalos; a demarcação de terras indígenas; a implementação do sistema de cotas em universidades; a fidelidade partidária; a distribuição de medicamentos; a liberdade de expressão na imprensa; a delimitação do campo de autonomia das agências reguladoras; o reconhecimento da união de pessoas do mesmo sexo para fins de previdência (união homoafetiva) etc. (Taylor, 2007; Vieira, 2009; Sadek, 2011).

Ao ser chamado a decidir sobre temas de interesse público e responder a este chamado, o Supremo aumenta sua influência sobre a agenda de políticas públicas e assevera o processo de transferência decisória dos Poderes Legislativo e Executivo para o Judiciário. Passa então a exercitar a revisão das regras do jogo político.

Esta crescente influência e centralidade do Judiciário no cenário político nacional, com o STF 
dando a última palavra em temas tão importantes e variados como os citados acima, e a superexposição do Supremo na mídia, levou Vieira (2009) a cunhar o termo "supremocracia". Por supremocracia o autor entende o acúmulo de autoridade do tribunal no seu papel de intérprete da constituição e na criação de regras. O STF teve sua autoridade expandida tanto em relação às demais instâncias do Poder Judiciário quanto em relação aos demais poderes do Estado.

A ampliação dos instrumentos ofertados para a jurisdição constitucional tem levado o Supremo não apenas a exercer uma espécie de poder moderador, mas também de responsável por emitir a última palavra sobre inúmeras questôes de natureza substantiva, ora validando e legitimando uma decisão dos órgãos representativos, outras vezes substituindo as escolhas majoritárias. Se esta é uma atribuição comum a outros tribunais constitucionais ao redor do mundo, a distinção do Supremo é de escala e de natureza. Escala pela quantidade de temas que, no Brasil, têm natureza constitucional e são reconhecidas pela doutrina como passíveis de judicialização; de natureza, pelo fato de não haver qualquer obstáculo para que o Supremo aprecie atos do poder constituinte reformador (Vieira, 2009, p. 445).

A discussão sobre a expansão do Poder Judiciário na política não é nova. Vallinder (1995) conceitua essa expansão como judicialização da política, referindo-se "a expansão da área de atuação das cortes judiciais ou dos juízes as expensas dos políticos e/ou administradores, isto é, a transferência de direitos de decisão da legislatura, do gabinete ou da administração pública às cortes judiciais, ou, ao menos, a propagação dos métodos judiciais de decisão para fora das cortes de direito propriamente ditas" (1995, p. 13).

Autores como Castro (1997) e Vianna et al. (1999) procuraram aplicar este conceito de judicialização da política à realidade brasileira.

Atualmente, o conceito é largamente utilizado e ganhou diferentes contornos, referindo-se a aspectos tão diversificados da participação do Ju- diciário na política, que aqui procuramos evitá-lo, referindo-nos tão somente às relaçôes entre Judiciário e política. ${ }^{1}$

A relação entre Poder Judiciário e política no Brasil e a forma pela qual os tribunais participam do processo decisório pode ser discutida basicamente em quatro âmbitos: (1) desenho institucional; (2) usos do tribunal; (3) dinâmica interna; e (4) reação às decisões do tribunal (compliance).

A discussão sobre o desenho institucional refere-se aos aspectos que possibilitam ao Judiciário ter impacto nas decisões políticas e às ferramentas que possibilitam ao juiz exercer um papel político. Um dos estudos de maior destaque nesse âmbito é o de Taylor (2008). O argumento do autor é de que as cortes desempenham um importante papel no processo político e a maneira pela qual estão estruturadas influencia esse papel. Taylor demonstra como as características institucionais do sistema judiciário brasileiro (suas estruturas burocráticas, seus arranjos constitucionais e institucionais, e os instrumentos legais e normas profissionais) influenciam a discussão acerca das políticas públicas e afetam seus resultados, determinando quem tem acesso às cortes, como, quando e onde o Judiciário influencia a política.

Outros textos clássicos que abordam os aspectos do desenho institucional são os de Vieira (1994) e Arantes (1997), discutindo o papel político desempenhado pelo Judiciário a partir da configuração e do funcionamento dos mecanismos de controle de constitucionalidade das leis no Brasil é a institucionalização do controle de constitucionalidade das leis, o exercício do judicial review, o que possibilita, antes de qualquer coisa, a relação entre direito e política.

Dado o desenho institucional do STF e as características que possibilitam a ele atuar na esfera da política, é fundamental olhar para como diversos atores acionam esse Poder e quais as oportunidades dadas ao Judiciário para o exercício de influência na política. O Judiciário é um poder reativo, dependendo do acionamento de outros atores para exercer sua jurisdição. Assim, se discute como os tribunais são ativados externamente por diversos atores para arbitrar conflitos entre Legislativo e Executivo, entre os componentes da federação e entre Estado e 
sociedade civil. Inserem-se nesse âmbito de análise a discussão do Judiciário como um mecanismo de checks and balances, sua atuação como instituição contra-majoritária (quando revê decisões da maioria parlamentar constrangendo o poder dos governantes tendo em vista a proteção da Constituição e a proteção dos direitos das minorias) e também como instituição majoritária (quando reafirma decisōes da maioria), e ainda como canalizadora de interesses e reivindicaçôes societárias (Vianna et al., 1999; Garapon, 2001; Taylor, 2008; Taylor e Da Ros, 2008).

Taylor (2008) afirma que o uso das cortes no Brasil é frequentemente político e o conteúdo expansivo da Constituição de 1988 e os privilégios que ela forneceu a determinados atores políticos (veto players) para acionarem diretamente o STF contribuíram para assegurar a judicialização da política no país, posicionando o Supremo como alternativa aos policymakers tradicionais. Segundo o autor, além das características institucionais do sistema judicial, também os custos e benefícios das políticas são variáveis importantes: políticas com custos concentrados e benefícios difusos são as mais prováveis de enfrentarem questionamentos legais.

Taylor atenta ainda para o fato de que existem objetivos estratégicos que motivam a judicialização de uma questão. Assim, nem sempre os atores buscam única e exclusivamente reverter ou retirar uma lei do ordenamento jurídico pela sua inconstitucionalidade, mas podem, por exemplo, buscar demarcar oposição ou tentar desacreditar o governo ou o parlamento. Segundo Taylor, são quatro os objetivos estratégicos que podem motivar o questionamento de uma lei ou ato normativo no tribunal: "delay, disable, discredit, declare opposition" (Taylor, 2008, p. 10).

Uma vez que o Poder Judiciário é acionado para arbitrar interesses em conflito, é importante observar a dinâmica interna de decisão e as respostas por ele dadas às demandas recebidas.

As perguntas que se procuram responder neste âmbito de análise são relativas ao padrão interno de decisão individual (Como os juízes decidem os casos?) e coletivo (Quais são os fatores que determinam as decisões finais do tribunal?). Ou seja, qual a orientação da política do Poder Judiciário e que fatores influenciam a formação das políticas judiciais (Oliveira, 2008, 2011; Ribeiro, Arguelhes e Peixoto, 2009).

São quatro as principais abordagens na análise do processo interno de decisão judicial: (1) legal, (2) atitudinal, (3) estratégica e (4) institucional.

A proposição da abordagem legal é de que os juízes decidem os casos aplicando as regras e os princípios incorporados nos precedentes legais e na doutrina, baseando-se em princípios morais e políticos e não em preferências políticas propriamente ditas. Um dos principais autores a defender esta posição é Dworkin (1998). Os críticos do modelo legal afirmam que tal abordagem se limitaria a considerar como centrais quatro variáveis: o pleno significado do texto constitucional; a intenção dos legisladores; os precedentes e o balanceamento entre os interesses constitucionais e os interesses societários (ver Segal e Spaeth, 1993).

Já a abordagem atitudinal critica a legal, propondo que os juízes determinam suas decisões com base em suas preferências políticas pessoais, seus valores e suas convicções ideológicas. Os principais expoentes desta linha são Segal e Spaeth (2002). As principais variáveis na explicação do comportamento dos juízes são a posição ideológico-partidária do juiz e o presidente que o nomeou. Variáveis de background social e econômico influenciam este comportamento de maneira residual, assim como a composição do Congresso e a opinião pública. $\mathrm{O}$ argumento central do modelo atitudinal é de que os juízes procuram traduzir suas preferências pessoais de natureza político-ideológica em jurisprudência constitucional - e dado que eles dispõem de garantias que lhes dão independência frente ao governo e outros atores políticos, o fazem com relativa facilidade.

De acordo com Segal e Spaeth (2002), uma vez que atitudes e valores dos juízes determinam as decisões, a nomeação presidencial dos juízes passa a ser a variável mais importante para compreender a decisão judicial.

A abordagem estratégica afirma que o comportamento de decisão dos juízes depende de suas preferências ideológicas, mas é constrangido por forças políticas, sociais e institucionais. Os juízes fazem escolhas quando decidem, mas estas esco- 
lhas são estratégicas na medida em que consideram as expectativas e escolhas de atores externos envolvidos na questão a ser decidida. Epstein e Knight (2001) são os autores chave do modelo estratégico. As variáveis utilizadas nesse modelo são divididas em dois grupos: internas (que focam os juízes e suas relaçōes no tribunal) e externas (que focam os constrangimentos impostos à corte por outros atores políticos).

E por fim, a abordagem institucional, que considera que o papel político desempenhado pelo Poder Judiciário, sofre constrangimentos não apenas de atores externos mais também do próprio contexto institucional no qual os juízes estão inseridos. As decisões judiciais são elas mesmas constituídas e estruturadas pelo tribunal como uma instituição e por sua relação com outras instituições no sistema político como um todo (Feldman, 2005, p. 92). A abordagem institucional faz uma espécie de síntese dos modelos anteriores, afirmando que a decisão judicial sofre influência do treinamento e da posição ideológica dos juízes, mas que o elemento determinante é o contexto institucional.

O posicionamento de Gibson (1983) ilustra bem a necessidade de não tomar nenhum aspecto isolado, seja o perfil ideológico dos juízes, sejam os aspectos legais como precedentes etc. Segundo o autor, "teorias do comportamento judicial devem tornar-se mais complexas se quiserem atingir um maior nível de explicação e previsão" (1983, p. 7). Os juízes não são agentes completamente livres, suas escolhas são orientadas e restringidas pela Constituição, por precedentes, por receio de sanções, sendo suas decisões tomadas dentro do contexto do grupo e da instituição ao qual pertencem.

Segundo Gibson, "as decisões dos juízes são uma função do que eles preferem fazer, moderadas pelo que eles pensam que deveriam fazer, mas constrangidas pelo o que percebem que é possível fazer. Os indivíduos tomam decisões, mas o fazem no contexto de restriçôes do grupo, institucionais e ambientais. Assim, para compreender o processo decisório, são necessários não apenas modelos multivariados, mas esses modelos devem ser capazes de incorporar os efeitos operacionais em níveis variados de análise" (1983, p. 32). Essa é a perspectiva que seguimos neste estudo.
Após deliberação e decisão do tribunal, é preciso considerar a recepção a essa decisão pelos demais poderes e pela opinião pública. Quais os impactos das decisões judiciais para o sistema político e qual o efeito que estas decisões têm na implementação de políticas públicas? Quais as reações dos atores políticos e da opinião pública às escolhas que os juízes fazem?

Os demais poderes podem aceitar e cumprir as decisões ou ignorá-las. E algumas vezes inclusive retaliar a corte. Helmke e Staton (2009) sugerem que a relação entre os três poderes do Estado segue um jogo de informação incompleta, em que os juízes agem estrategicamente para evitar que suas decisões sejam derrubadas ou ignoradas, e seus postos ameaçados. Assim, tendem a ser prudentes. Mas ao mesmo tempo valorizam sua posição e seu papel, e para garanti-lo precisam manter a confiança da sociedade na corte, respondendo aos seus anseios, para que litigantes continuem a levar casos importantes para sua apreciação.

Os autores afirmam que há uma série de razões para os demais poderes respeitarem as decisões do Judiciário uma vez que ele serve a uma variedade de fins políticos, como garantir a confiança dos investidores nos direitos de propriedade e no rule of law, garantir as regras do jogo político, assegurando a alternância no poder e precavendo-os contra futuras perdas eleitorais. Por outro lado, afirmam que há possibilidades para ameaças, indicando que as Supremas Cortes na América Latina vêm sofrendo retaliações por parte dos Poderes Executivo e Legislativo, nas últimas três décadas, em virtude de decisões que tomaram contrariando esses poderes.

Os autores indicam que foram cerca de catorze ataques no início da década de 1990 e contabilizam uma média de onze ataques a cada cinco anos desde então. Exemplificam com o caso de packing the court na Argentina, em 1990, com o impeachment de juízes no Peru, em 1997 e com a dissolução da corte na Venezuela, em 1999. Já no Brasil, o Supremo não sofreu nenhum ataque deste tipo desde a redemocratização do país, em 1988.

Esses quatro aspectos (desenho institucional, usos do tribunal, dinâmica interna e reação às decisões do tribunal) são essenciais para termos um retrato completo da influência do Poder Judiciário na política. 
Aqui voltamos nossa atenção para o terceiro aspecto: a dinâmica interna. $\mathrm{O}$ objetivo é discutir o processo de decisão do STF, focando na forma como os ministros respondem aos casos quando são acionados. Observamos os casos de Ações Diretas de Inconstitucionalidade que questionam normas federais, tratando de questôes de relevo nacional, e também as açóes que questionam normas estaduais ${ }^{2}$ e normas que têm origem no próprio Judiciário ou em agências reguladoras do Estado. ${ }^{3}$ Buscamos mapear os padrões de decisão e os fatores que informam essas decisões.

Discutimos ainda um dos assuntos mais polêmicos (tanto no mundo acadêmico quanto no mundo político) relativos ao tribunal - o impacto da nomeação presidencial no direcionamento das decisōes dos ministros. Alguns acadêmicos e estudiosos do STF, ao constatarem que o tribunal, em suas decisóes, tende a ser favorável ao Governo Federal, associam esse comportamento à subserviência dos ministros: uma vez nomeados por um governo, os ministros tenderiam a representar os interesses desse governo no tribunal, reforçando o argumento da falta de independência do Poder Judiciário. Examinamos como a renovação na composição refletiu-se em mudanças na orientação das decisóes do tribunal como um todo.

$\mathrm{O}$ artigo que segue está estruturado em dois grandes blocos. No primeiro fazemos uma análise descritiva das decisões do tribunal no período e no segundo modelamos os fatores de maior impacto nas decisōes e no processo decisório do Supremo.

\section{As ADIns e o processo decisório no STF}

Concentraremos nossa atenção nas ADIns, uma vez que elas são o instrumento principal e mais conhecido dos atores para influenciar a política pela via judicial. E como afirma Taylor (2008), as ADIns são ouvidas de forma relativamente rápida e os seus efeitos são vinculativos e não podem ser objeto de recurso. As ADIns são hoje um instrumento importante para se fazer política no Brasil. Nas palavras de Vianna et al. (2007):

As ADIns já fazem parte do cenário natural da moderna democracia brasileira, afirmando ano após ano, ao longo de quase duas décadas, em sucessivos e diferentes governos, a sua presença institucional, e mais fortemente ainda no atual governo Lula. Como escoadouro de conflitos entre sociedade e Estado, dos que nascem no próprio interior da administração pública e da federação, e instrumento de trabalhadores e empresários, elas fazem com que o país, sob a forma como se apresenta hoje, não seja mais governável sem elas. Aqui, além de ser instrumento da defesa de minorias, sua origem constitucional clássica, a ADI também é recurso institucional estratégico de governo, instituindo, na prática, o Supremo Tribunal Federal como um conselho de Estado do tipo prevalecente em países de configuração unitária (Vianna et al., 2007, pp. 43-44).

De outubro de 1988 até dezembro de 2009 foram distribuídas no Supremo Tribunal Federal 4.353 ADIns. Na distribuição por ano notamos uma queda acentuada do acionamento do STF via ADI a partir de $2005 .{ }^{4}$

Do total de ADIns distribuídas até 2009, $66 \%$ tiveram a decisão final proferida, $10 \%$ tiveram decisão liminar (e estão ainda aguardando julgamento final) e $24 \%$ aguardavam, sem nenhum tipo de decisão.

Das ações com decisão final julgada (2.853), $64 \%$ não foram conhecidas, $6 \%$ foram declaradas improcedentes e $30 \%$ procedentes na totalidade ou em parte. Ou seja, foram 866 decisōes finais deferidas total ou parcialmente. Assim, pode-se dizer que as chances de alterar a norma contestada via ADIn são quase de uma em três, o que é bastante expressivo.

Esse resultado fica ainda mais expressivo quando consideramos, junto com Taylor (2008), que os usos do tribunal nem sempre são com o objetivo de ver a norma derrubada, havendo outros objetivos estratégicos que motivam a judicialização de uma questão (como ganhar tempo e atrasar a implementação de políticas públicas ou como uma forma de declarar publicamente oposição à norma ou política pública em questão e chamar a atenção da mídia e da opinião pública para o caso etc.). E mais ainda, como afirmam Kapiszewski e Taylor (2008), os governos na maioria das vezes agem de forma 


\section{Gráfico 1}

Movimentação Processual no STF: Quantidade de ADIns Distribuídas e Julgadas por Ano

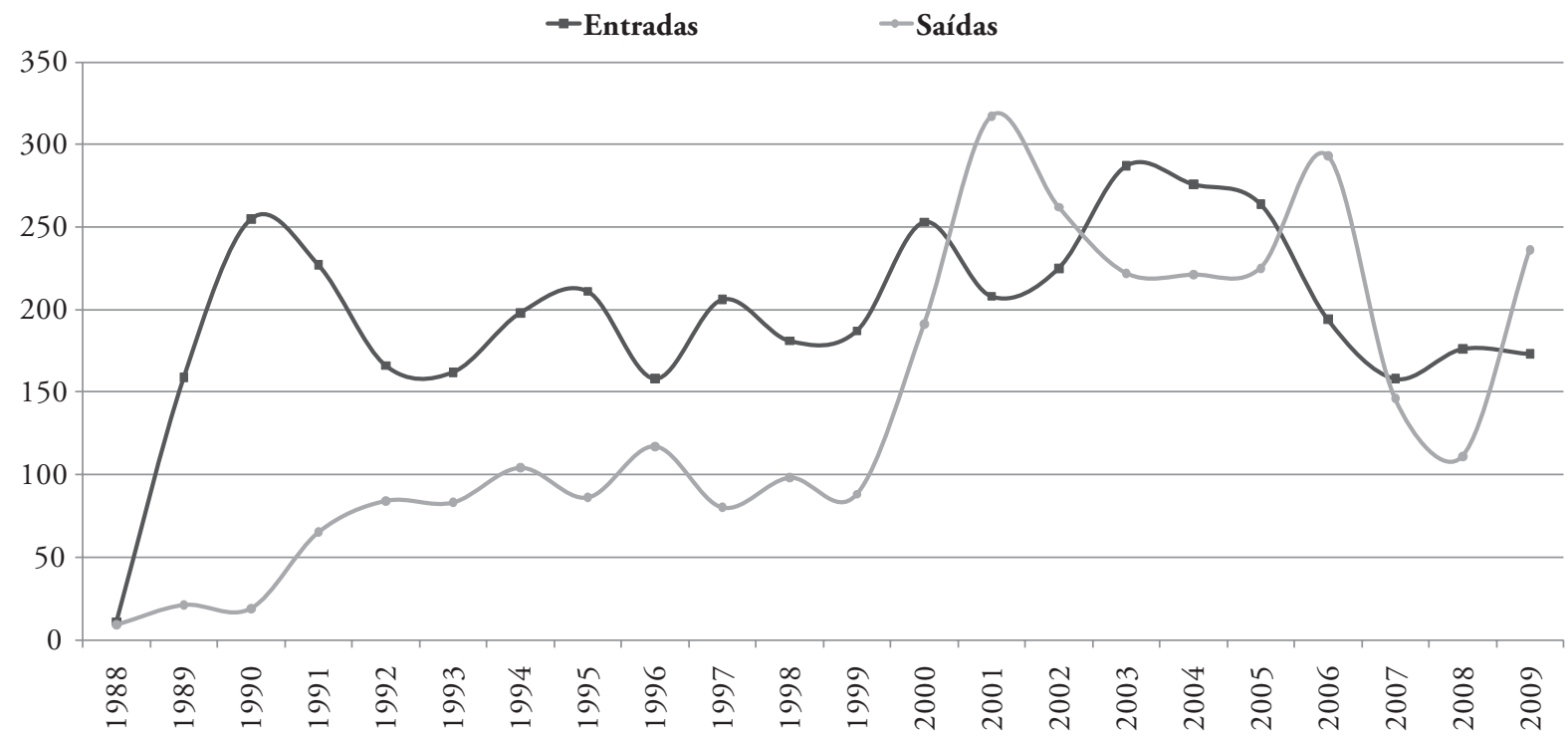

Fonte: Supremo em Números (www.supremoemnumeros.com.br).

Gráfico 2

Movimentação Processual no STF: Situação de Julgamento das ADIns, em \%

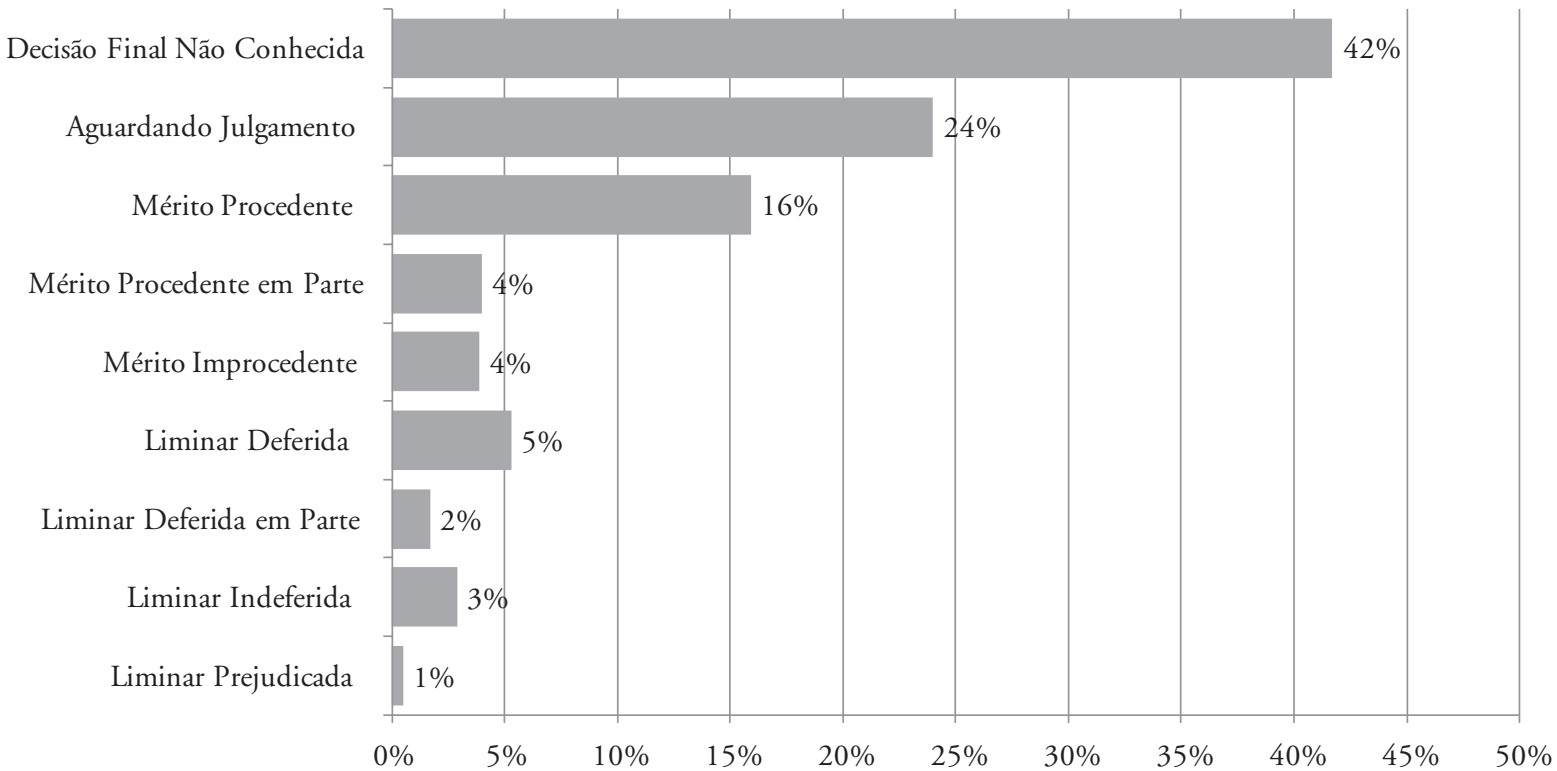

Base: 4.353 ADIns, distribuídas entre outubro de 1988 e dezembro de 2009.

Fonte: elaborado a partir de estatísticas do STF (www.stf.gov.br). 
constitucional. Portanto, não há por que esperar de antemão que todas as normas contestadas sejam consideradas inconstitucionais.

Isto posto, os dados gerais de movimentação das ADIns no Supremo não permitem, em princípio, afirmar que o tribunal tem se furtado a desempenhar seu papel, ou tem agido timidamente, ainda que um grande volume de ações não tenha sido conhecida. É preciso observar antes o perfil dessas ações não conhecidas, quem são os proponentes, qual a origem da norma contestada e a fundamentação para o tribunal não ter conhecido da ação.

Note-se que $52 \%$ das ADIns não conhecidas (1.826) foram justificadas pela ilegitimidade ativa do proponente.

Taylor afirma que muitas vezes os juízes se utilizam de soluçôes discricionárias para evitar decidir sobre questões politicamente delicadas, e que esta tática não é exclusividade dos juízes brasileiros, sendo comum também entre americanos e europeus. O não conhecimento de ADIns pode tratar-se de estratégia para evitar essas questóes políticas, uma espécie de "writ of certiorary informal" (Veríssimo, 2008; Vieira, 2009) para controlar melhor a agenda do tribunal. ${ }^{5}$

\section{Recorte temporal - composição do STF entre os governos FHC e Lula}

Escolhemos para este estudo um momento de transição de governos: entre o segundo governo FHC (1999-2002) e o primeiro governo Lula (2003-2006). Esta escolha se baseia em uma opção metodológica, pois o período nos permite observar e controlar tanto a mudança de agenda política, dada a distinta ideologia dos governos, quanto uma mudança também na instituição, reflexo da nomeação de novos ministros ao tribunal.

A composição do STF entre 1999 e 2006 mudou significativamente. Organizando cronologicamente a saída de ministros e a entrada de novos membros no tribunal, podemos falar em "cortes", ou seja, cada corte é uma composição fixa de ministros, e as cortes mudam conforme esta composição se altera. Podemos, então, afirmar que no período analisado houve sete diferentes composiçôes ou “cortes”, como sumarizado no Quadro 1.
É importante destacar que desde a promulgação da Constituição de 1988 até 2010, a maior mudança no quadro do STF se deu entre os governos FHC e o primeiro governo Lula - o que reforça nossa opção metodológica de analisar esse período.

Fernando Collor nomeou quatro ministros (Carlos Mário da Silva Velloso; Ilmar Nascimento Galvão; José Francisco Rezek; Marco Aurélio Mendes de Farias Mello); Itamar Franco nomeou um ministro (Maurício José Corrêa); Fernando Henrique Cardoso nomeou três ministros (Ellen Gracie Northfleet; Gilmar Ferreira Mendes; Nelson Azevedo Jobim); e Lula, em seu primeiro mandato, nomeou seis ministros (Antonio Cezar Peluso; Carlos Augusto Ayres de Freitas Britto; Joaquim Benedito Barbosa Gomes; Eros Roberto Grau; Enrique Ricardo Lewandowski; Cármen Lúcia Antunes Rocha).

No Quadro 2 traçamos a trajetória de carreira destes ministros, dando atenção à passagem por carreiras públicas do Direito (em especial o Judiciário - PJ - e o Ministério Público - MP), assim como sua passagem por cargos políticos, sejam majoritários, proporcionais ou ainda cargos de indicação do Executivo (como ministérios e secretarias).

Notamos que com o passar do tempo diminuiu a predominância de ministros com carreira no Judiciário e com trajetória na política e a carreira no MP permaneceu constante, como o principal background de formação dos ministros (Gráfico 3).

Os dados sobre a trajetória profissional dos ministros do Supremo mostraram-se determinantes para explicar seu comportamento de voto (Oliveira, 2008). Assim, utilizamos em nossa análise tanto as mudanças na composição global do tribunal quanto a trajetória de carreira dos ministros como um dos preditores do posicionamento final do tribunal.

Taylor e Da Ros (2008) estudaram esse mesmo período, mas sob ótica diferente. O interesse deles foi analisar os padrões de judicialização da política nestas duas administrações presidenciais procurando por variaçôes no acionamento do Supremo apenas na contestação de normas federais. Taylor e Da Ros observaram o segundo aspecto da discussão: o uso que atores específicos fazem das cortes.

Os autores identificaram três usos dos tribunais quando se trata de questionar normas federais: 
Quadro 1

Composição do Tribunal de acordo com Nomeação de Novos Ministros

\begin{tabular}{|c|c|c|}
\hline Corte & Período & Composição \\
\hline 1 & $\begin{array}{l}1 / 1 / 1999 \\
\mathrm{a} \\
22 / 11 / 2000\end{array}$ & $\begin{array}{l}\text { 1. Moreira Alves } \\
\text { 2. Néri da Silveira } \\
\text { 3. Sydney Sanches } \\
\text { 4. Octavio Gallotti } \\
\text { 5. Sepúlveda Pertence } \\
\text { 6. Celso de Mello } \\
\text { 7. Carlos Velloso } \\
\text { 8. Marco Aurélio } \\
\text { 9. Ilmar Galvão } \\
\text { 10. Maurício Corrêa } \\
\text { 11. Nélson Jobim }\end{array}$ \\
\hline 2 & $\begin{array}{l}23 / 11 / 2000 \\
\mathrm{a} \\
26 / 5 / 2002\end{array}$ & $\begin{array}{l}\text { 1. Moreira Alves } \\
\text { 2. Néri da Silveira } \\
\text { 3. Sydney Sanches } \\
\text { 4. Sepúlveda Pertence } \\
\text { 5. Celso de Mello } \\
\text { 6. Carlos Velloso } \\
\text { 7. Marco Aurélio } \\
\text { 8. Ilmar Galvão } \\
\text { 9. Maurício Corrêa } \\
\text { 10. Nélson Jobim } \\
\text { 11. Ellen Gracie }\end{array}$ \\
\hline 3 & $\begin{array}{l}27 / 5 / 2002 \\
\mathrm{a} \\
24 / 6 / 2003\end{array}$ & $\begin{array}{l}\text { 1. Moreira Alves } \\
\text { 2. Sydney Sanches } \\
\text { 3. Sepúlveda Pertence } \\
\text { 4. Celso de Mello } \\
\text { 5. Carlos Velloso } \\
\text { 6. Marco Aurélio } \\
\text { 7. Ilmar Galvão } \\
\text { 8. Maurício Corrêa } \\
\text { 9. Nélson Jobim } \\
\text { 10. Ellen Gracie } \\
\text { 11. Gilmar Mendes }\end{array}$ \\
\hline
\end{tabular}

\begin{tabular}{|c|c|c|}
\hline Corte & Período & Composição \\
\hline 4 & $\begin{array}{l}25 / 6 / 2003 \\
\mathrm{a} \\
14 / 6 / 2004\end{array}$ & $\begin{array}{l}\text { 1. Sepúlveda Pertence } \\
\text { 2. Celso de Mello } \\
\text { 3. Carlos Velloso } \\
\text { 4. Marco Aurélio } \\
\text { 5. Maurício Corrêa } \\
\text { 6. Nélson Jobim } \\
\text { 7. Ellen Gracie } \\
\text { 8. Gilmar Mendes } \\
\text { 9. Cesar Peluso } \\
\text { 10. Ayres Brito } \\
\text { 11. Joaquim Barbosa }\end{array}$ \\
\hline 5 & $\begin{array}{l}15 / 6 / 2004 \\
\text { a } \\
15 / 2 / 2006\end{array}$ & $\begin{array}{l}\text { 1. Sepúlveda Pertence } \\
\text { 2. Celso de Mello } \\
\text { 3. Carlos Velloso } \\
\text { 4. Marco Aurélio } \\
\text { 5. Nélson Jobim } \\
\text { 6. Ellen Gracie } \\
\text { 7. Gilmar Mendes } \\
\text { 8. Cesar Peluso } \\
\text { 9. Ayres Brito } \\
\text { 10. Joaquim Barbosa } \\
\text { 11. Eros Grau }\end{array}$ \\
\hline 6 & $\begin{array}{l}16 / 2 / 2006 \\
a \\
20 / 6 / 2006\end{array}$ & $\begin{array}{l}\text { 1. Sepúlveda Pertence } \\
\text { 2. Celso de Mello } \\
\text { 3. Marco Aurélio } \\
\text { 4. Nélson Jobim } \\
\text { 5. Ellen Gracie } \\
\text { 6. Gilmar Mendes } \\
\text { 7. Cesar Peluso } \\
\text { 8. Ayres Brito } \\
\text { 9. Joaquim Barbosa } \\
\text { 10. Eros Grau } \\
\text { 11. Ricardo Lewandowski }\end{array}$ \\
\hline 7 & $\begin{array}{l}21 / 6 / 2006 \\
\text { a } \\
31 / 12 / 2006\end{array}$ & $\begin{array}{l}\text { 1. Sepúlveda Pertence } \\
\text { 2. Celso de Mello } \\
\text { 3. Marco Aurélio } \\
\text { 4. Ellen Gracie } \\
\text { 5. Gilmar Mendes } \\
\text { 6. Cesar Peluso } \\
\text { 7. Ayres Brito } \\
\text { 8. Joaquim Barbosa } \\
\text { 9. Eros Grau } \\
\text { 10. Ricardo Lewandowski } \\
\text { 11. Carmen Lúcia }\end{array}$ \\
\hline
\end{tabular}




\section{Quadro 2}

Trajetória de Carreira dos Ministros que Compuseram o STF no Período Analisado

\begin{tabular}{|c|c|c|c|c|c|c|c|c|c|}
\hline Cód. & Ministro & $\begin{array}{l}\text { Faculdade/ } \\
\text { Graduação }\end{array}$ & $\begin{array}{l}\text { Cargo ocupado } \\
\text { antes da } \\
\text { nomeaçáo }\end{array}$ & $\begin{array}{l}\text { Presidente } \\
\text { que } \\
\text { nomeou }\end{array}$ & Entrada & Saída & PJ & MP & Política \\
\hline 1 & $\begin{array}{l}\text { José Carlos } \\
\text { Moreira Alves }\end{array}$ & UnB-RJ & $\begin{array}{l}\text { Procurador-Geral } \\
\text { da República }\end{array}$ & $\begin{array}{l}\text { Ernesto } \\
\text { Geisel }\end{array}$ & $18 / 6 / 1975$ & $22 / 4 / 2003$ & Não & Sim & Sim \\
\hline 2 & $\begin{array}{l}\text { José Néri da } \\
\text { Silveira }\end{array}$ & PUC-RS & Juiz do TFR & $\begin{array}{l}\text { João } \\
\text { Figueiredo }\end{array}$ & $1 / 9 / 1981$ & $23 / 4 / 2002$ & Sim & Não & Não \\
\hline 3 & Sydney Sanches & $\begin{array}{l}\text { Largo São. } \\
\text { Francisco } \\
\text { (USP) }\end{array}$ & $\begin{array}{l}\text { Desembargador } \\
\text { do TJSP }\end{array}$ & $\begin{array}{l}\text { João } \\
\text { Figueiredo }\end{array}$ & $13 / 8 / 1984$ & $24 / 4 / 2003$ & Sim & Não & Não \\
\hline 4 & $\begin{array}{l}\text { Luiz Octavio Pires } \\
\text { e Albuquerque } \\
\text { Gallotti }\end{array}$ & UnB-RJ & $\begin{array}{l}\text { Ministro Tribunal } \\
\text { de Contas da } \\
\text { União }\end{array}$ & $\begin{array}{l}\text { João } \\
\text { Figueiredo }\end{array}$ & $20 / 11 / 1984$ & $27 / 10 / 2000$ & Não & Sim & Não \\
\hline 5 & $\begin{array}{l}\text { José Paulo } \\
\text { Sepúlveda } \\
\text { Pertence }\end{array}$ & UFMG & $\begin{array}{l}\text { Procurador-Geral } \\
\text { da República }\end{array}$ & José Sarney & $4 / 5 / 1989$ & $17 / 9 / 2007$ & Não & Sim & Não \\
\hline 6 & $\begin{array}{l}\text { José Celso de } \\
\text { Mello Filho }\end{array}$ & $\begin{array}{l}\text { Largo São. } \\
\text { Francisco } \\
\text { (USP) }\end{array}$ & $\begin{array}{l}\text { Secretário } \\
\text { Consultoria Geral } \\
\text { da Presidência da } \\
\text { República }\end{array}$ & José Sarney & $30 / 6 / 1989$ & $01 / 11 / 2015^{*}$ & Não & Sim & Sim \\
\hline 7 & $\begin{array}{l}\text { Carlos Mário da } \\
\text { Silva Velloso }\end{array}$ & UFMG & Ministro do STJ & $\begin{array}{l}\text { Fernando } \\
\text { Collor }\end{array}$ & $28 / 5 / 1990$ & $19 / 1 / 2006$ & Sim & Sim & Não \\
\hline 8 & $\begin{array}{l}\text { Marco Aurélio } \\
\text { Mendes de Farias } \\
\text { Mello }\end{array}$ & UFRJ & $\begin{array}{l}\text { Corregedor-Geral } \\
\text { da Justiça do } \\
\text { Trabalho }\end{array}$ & $\begin{array}{l}\text { Fernando } \\
\text { Collor }\end{array}$ & $28 / 5 / 1990$ & $12 / 7 / 2016^{*}$ & Sim & Sim & Não \\
\hline 9 & $\begin{array}{l}\text { Ilmar Nascimento } \\
\text { Galvão }\end{array}$ & UnB-RJ & Ministro do STJ & $\begin{array}{l}\text { Fernando } \\
\text { Collor }\end{array}$ & $12 / 6 / 1991$ & $2 / 5 / 2003$ & Sim & Não & Não \\
\hline 10 & $\begin{array}{l}\text { Maurício José } \\
\text { Corrêa }\end{array}$ & UFMG & $\begin{array}{l}\text { Ministro da } \\
\text { Justiça }\end{array}$ & $\begin{array}{l}\text { Itamar } \\
\text { Franco }\end{array}$ & $27 / 10 / 1994$ & $9 / 5 / 2004$ & Não & Não & Sim \\
\hline 11 & $\begin{array}{l}\text { Nelson Azevedo } \\
\text { Jobim }\end{array}$ & UFRS & $\begin{array}{l}\text { Ministro da } \\
\text { Justiça }\end{array}$ & FHC & $7 / 4 / 1997$ & $29 / 3 / 2006$ & Não & Não & Sim \\
\hline 12 & $\begin{array}{l}\text { Ellen Gracie } \\
\text { Northfleet }\end{array}$ & UFRS & Juiz do TFR & FHC & $14 / 12 / 2000$ & $5 / 8 / 2011$ & Sim & Sim & Não \\
\hline 13 & $\begin{array}{l}\text { Gilmar Ferreira } \\
\text { Mendes }\end{array}$ & UnB-Brasília & $\begin{array}{l}\text { Advogado-Geral } \\
\text { da União }\end{array}$ & FHC & $27 / 5 / 2002$ & $30 / 12 / 2025^{*}$ & Não & Sim & Sim \\
\hline 14 & $\begin{array}{l}\text { Antonio Cezar } \\
\text { Peluso }\end{array}$ & $\begin{array}{l}\text { Universidade. } \\
\text { Católica de } \\
\text { Santos } \\
\end{array}$ & $\begin{array}{l}\text { Ministro do } \\
\text { Superior Tribunal } \\
\text { de Justiça }\end{array}$ & Lula & $5 / 6 / 2003$ & $03 / 09 / 2012^{*}$ & Sim & Não & Não \\
\hline 15 & $\begin{array}{l}\text { Carlos Augusto } \\
\text { Ayres de Freitas } \\
\text { Britto }\end{array}$ & UFS & Advogado & Lula & $5 / 6 / 2003$ & $18 / 11 / 2012^{*}$ & Não & Não & Não \\
\hline 16 & $\begin{array}{l}\text { Joaquim Benedito } \\
\text { Barbosa Gomes }\end{array}$ & UnB & $\begin{array}{l}\text { Procurador da } \\
\text { República }\end{array}$ & Lula & $25 / 6 / 2003$ & $7 / 12 / 2024^{*}$ & Não & Sim & Não \\
\hline 17 & $\begin{array}{l}\text { Eros Roberto } \\
\text { Grau }\end{array}$ & Mackenzie & Advogado & Lula & $15 / 6 / 2004$ & $19 / 8 / 2010$ & Não & Não & Não \\
\hline 18 & $\begin{array}{l}\text { Enrique Ricardo } \\
\text { Lewandowski }\end{array}$ & $\begin{array}{l}\text { Faculdade. } \\
\text { de Direito de } \\
\text { São Bernardo } \\
\text { do Campo }\end{array}$ & $\begin{array}{l}\text { Desembargador } \\
\text { do Tribunal de } \\
\text { Justiça de São } \\
\text { Paulo }\end{array}$ & Lula & $16 / 2 / 2006$ & $11 / 5 / 2018^{*}$ & Sim & Não & Não \\
\hline 19 & $\begin{array}{l}\text { Cármen Lúcia } \\
\text { Antunes Rocha }\end{array}$ & PUC-MG & $\begin{array}{l}\text { Procuradora-Geral } \\
\text { do Estado (MG) }\end{array}$ & Lula & $21 / 6 / 2006$ & $14 / 04 / 2024^{*}$ & Não & Sim & Não \\
\hline
\end{tabular}

* Compulsória aos 70 anos 


\section{Gráfico 3}

\section{Composição do STF nos Sete Períodos (cortes) de acordo com a Trajetória de Carreira dos Ministros (em \%)}

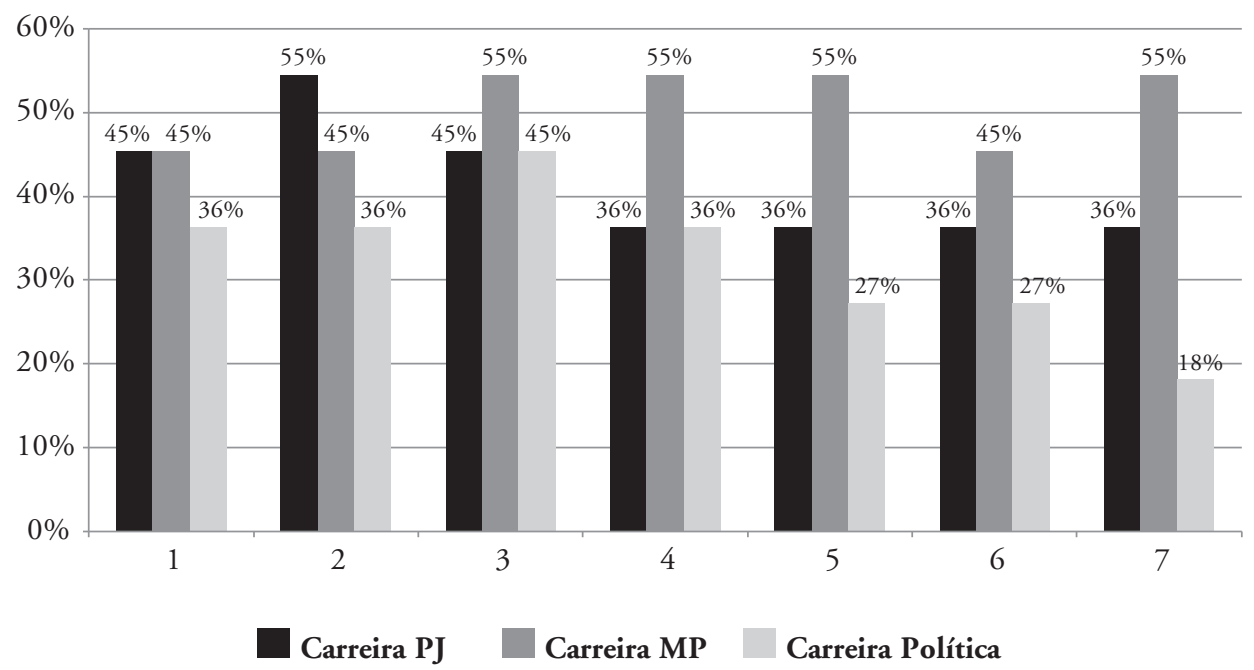

(1) judicialização como tática de oposição, ou seja, o Judiciário é acionado com o objetivo de declarar oposição ou desmerecer políticas públicas adotadas pelo governo; (2) judicialização como arbitragem de interesses em conflito, em que atores acionam o Judiciário com o objetivo de definir ou aperfeiçoar as regras do jogo que beneficiem um determinado ator ou um conjunto deles e por fim, (3) judicialização como instrumento de governo, quando o próprio governo aciona o Judiciário com o objetivo de alcançar decisão favorável a políticas públicas de interesse do seu governo, seja para superar situações de paralisia decisória ou de impasse legislativo, seja para anular estatutos legais e retirá-los do ordenamento jurídico (Taylor e Da Ros, 2008, p. 840).

A conclusão a que chegaram foi de uma queda brusca no uso do STF para o questionamento de políticas públicas federais do governo FHC para o governo Lula (redução de quase 60\%). E também constataram que houve variação no tipo de judicialização, sendo muito mais expressiva no governo FHC a judicialização como tática de oposição. Já no governo Lula a judicialização como instrumento de governo, que era praticamente inexistente no governo FHC, passou a ser utilizada.
Taylor e Da Ros apontam para dois principais fatores explicativos na mudança do padrão de judicialização entre um governo e outro: (1) diferença dos atores, levando à mudança nas estratégias de atuação e (2) mudança no contexto político e na saliência das políticas públicas implementadas em cada momento, sendo que as políticas centrais do governo Lula foram sensivelmente menos controversas do que as do governo FHC, e a alocação dos custos e benefícios das políticas entre "ganhadores" e "perdedores" mudou - lembrando que segundo Taylor (2008) políticas com custos concentrados e benefícios difusos tendem a ser mais contestadas judicialmente.

Os autores focaram no acionamento do STF; aqui nosso foco é na dinâmica interna, em como o tribunal recepcionou essas demandas e nas respostas que deu a cada um dos atores.

A maioria dos autores que abordam a dinâmica interna e o padrão de resposta do Supremo aponta para um conservadorismo em sua atuação, ou seja, o STF tem agido com cautela, esquivando-se de decidir. Ou ainda, afirmam que o Supremo tem decidido favoravelmente ao governo, quando o foco são questôes federais. 
Pacheco (2006) é uma das que apontam a baixa efetividade da atuação do tribunal. Ela estudou o desempenho do STF durante o primeiro governo FHC e o argumento da autora é de que o STF atua estrategicamente, decidindo questóes de baixa relevância nacional e de pouco impacto territorial. Segundo ela, o tribunal tem optado pela "não decisão" sistemática, procurando evitar a abertura de precedentes que venham a comprometer a produção de efeitos jurídicos dentro da ordem jurídica (Pacheco, 2006, p. 16).

Colombo (2001) afirma essa mesma tendência da jurisprudência do Supremo em acolher conflitos menos relevantes social e politicamente. $\mathrm{O}$ argumento central do autor é de que nas questôes políticas e econômicas mais relevantes no cenário nacional, as decisões do STF têm afirmado interesses e valores diferentes dos pressupostos e dos valores que informam a Constituição de 1988, alinhando-se às políticas de ajuste fiscal impostas por organismos internacionais (FMI e Banco Mundial, por exemplo). Segundo Colombo, o tribunal julga seletivamente de acordo com os interesses em jogo: quanto mais as ADIns se aproximam de questôes estratégicas para o governo, menos elas têm decisões favoráveis. O autor afirma a incoerência e as oscilações da jurisprudência do tribunal, em questôes de relevo concernentes à ordem política e financeira (cita o plano Collor, as privatizações e a emenda da reeleição). Assim, para o autor, o papel político desempenhado pelo Judiciário tem permitido a consolidação de significativas brechas de ilegalidade no funcionamento do ordenamento jurídico institucional brasileiro. Para o autor o STF atua a favor das políticas do Executivo.

A interpretação constitucional do STF desempenhou um papel decisivo para o ajuste da Constituição jurídica às diversas inconstitucionalidades praticadas pelo bloco de forças no poder. Nota-se um claro alinhamento entre a racionalidade material que permeou as principais decisões do tribunal e as diretrizes políticas estratégicas implementadas em larga escala por meio de procedimentos inconstitucionais que viabilizaram os interesses, valores e ideias das classes dominantes no período (Colombo, 2001, pp. 152).
Oliveira (2005) também argumenta que o STF tem se eximido de adotar uma postura política ativa e de promover uma interferência judicial em âmbitos eminentemente políticos. A autora analisa o papel que o tribunal desempenhou no processo de privatização de empresas estatais na década de 1990 com base no estudo das 27 ações que foram impetradas no Supremo contra processos de privatização. Ela constata que nenhuma das ações conseguiu barrar a venda das estatais, concluindo que a convergência entre a política do Executivo e a interpretação da Constituição dada pelo STF permitiu a continuidade do programa de privatizações.

Maranhão (2003) é outra a afirmar que o Supremo atua a favor do Executivo. A autora procura compreender como os ministros do STF decidem quando um dos agentes questionados é o presidente da República. Ela afirma que os presidentes eleitos têm procurado nomear ministros que, ainda que atendam às exigências formais da função, apresentem preferências políticas condizentes com a agenda presidencial, favorecendo a formação de uma maioria no tribunal que mantenha o status quo. Maranhão defende o argumento da subserviência dos ministros nomeados ao governo que os nomeou. Para ela, a subserviência se constata numa situação na qual o tribunal vote consistentemente com as preferências políticas do presidente da República. Ela observa que isso acontece em $85,9 \%$ das ADIns que questionam o Executivo Federal (Maranhão, 2003, p. 79).

Nosso argumento se opõe a essas explicações de parcimônia, procurando demonstrar que outros valores e outros fatores, ligados à instituição e à trajetória profissional dos ministros, podem explicar esse comportamento. Assim, analisamos as ADIns partindo dessa "constatação" da parcimônia e procurando nos opor a ela, buscando entender a orientação das decisões.

A principal diferença de nosso estudo para os anteriores é no recorte de seleção das ações a serem analisadas. Ao contrário destes estudos que limitaram suas análises às questôes de interesse do governo federal, focando em temas de grande impacto político nacional, nossa abordagem busca analisar a totalidade das respostas dadas pelo STF no período em análise: qual foi a agenda de decisão do 
STF em sede de controle de constitucionalidade no período? Que tipo de questôes ele julgou nos dois governos? O tipo de resposta dado foi diferente nos dois governos considerados?

\section{As ADIns e as respostas dadas pelo STF no periodo 1999-2006}

Enquanto o volume de acionamento entre o segundo governo FHC para o primeiro governo Lula aumentou $17,5 \%$, o volume de decisões nesse mesmo período aumentou em 23\% (Gráfico 4).

O tempo médio de decisão final de uma ADI no período analisado foi de 38,9 meses, com mediana de 18 meses, sendo o desvio padrão de 46,1 meses. A duração de um processo e o tempo que se leva para obter uma decisão final devem ser considerados na análise do resultado final de uma ação e é importante também para a compreensão da definição da agenda do tribunal.

O Supremo não absorve e julga toda a demanda que entra em determinado governo nesse mesmo governo, e comparando o governo FHC com o governo Lula, notamos que neste último o passivo de açôes de governos anteriores foi maior.

Das ADIns que tiveram decisão final julgada durante o primeiro governo Lula, $8 \%$ eram originárias do período anterior a 1995, 13\% do

\section{Gráfico 4}

Movimentação Processual: Distribuição de ADIns e Decisóes no Período de Interesse (valores absolutos)

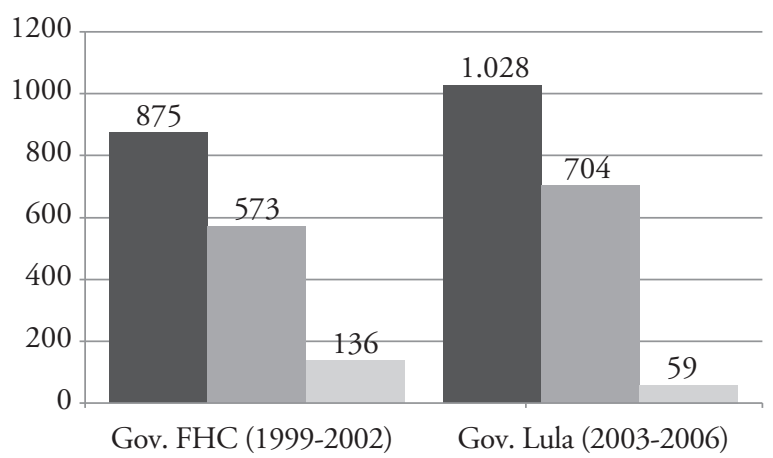

Total Distribuídas

Decisão Final (mérito)

Decisão liminar (aguardando mérito) primeiro governo $\mathrm{FHC}$ e $27 \%$ do segundo governo FHC e apenas $52 \%$ das ADIns decididas no primeiro governo Lula deram entrada no próprio governo Lula (Gráfico 5).

Em termos de respostas cautelares, no segundo governo $\mathrm{FHC}$ não houve passivo e no primeiro governo Lula 19\% eram provenientes de açóes entradas no governo anterior. E o tempo médio de decisão de uma liminar em ADI no período analisado foi de 8,7 meses, com mediana de 4 meses e desvio padrão de 17,1 meses (Gráfico 6).

Se assumirmos que os ministros guardam lealdade ao governo de sua nomeação ou mesmo que o tribunal tende a decidir mais favoravelmente ao governo, devemos esperar que ADIns decididas no mesmo governo em que deram entrada tendam a ser menos deferidas do que ADIns que são julgadas após o governo de entrada.

Neste artigo concentraremos nossa atenção nas ADIns que tiveram a decisão final proferida durante os dois governos, deixando de lado as ações que tiveram apenas a liminar julgada.

\section{Gráfico 5}

\section{Governo em que deu Entrada a ADI de acordo com o Governo em que foi julgada a Decisão Final da Ação (valores em \%)}

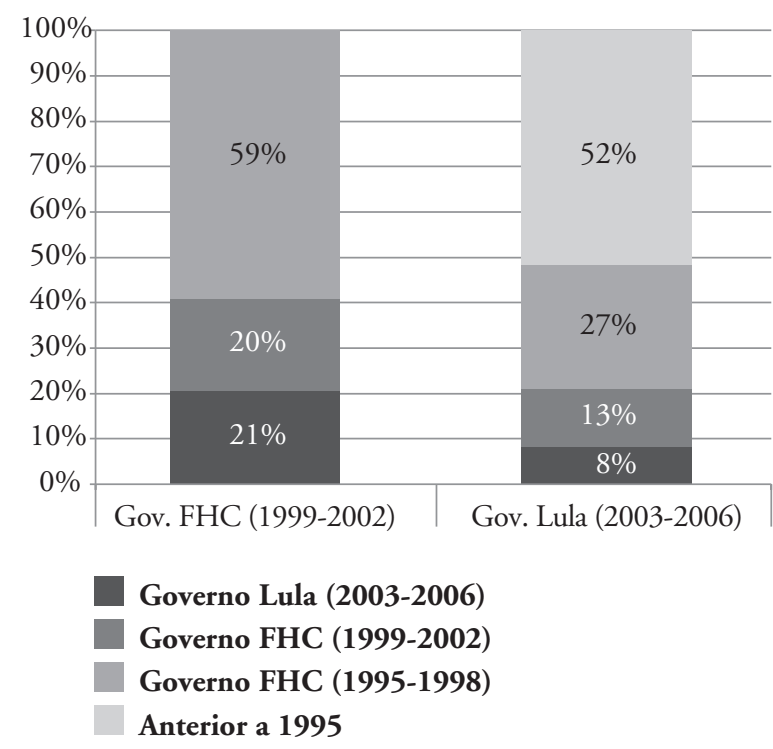

Base: 1.277 ADIns com decisão final julgadas entre janeiro de 1999 e dezembro de 2006. 


\section{Gráfico 6 \\ Governo em que deu Entrada a Ação de acordo com o Governo em que foi julgada Liminar da Ação (valores em \%)}

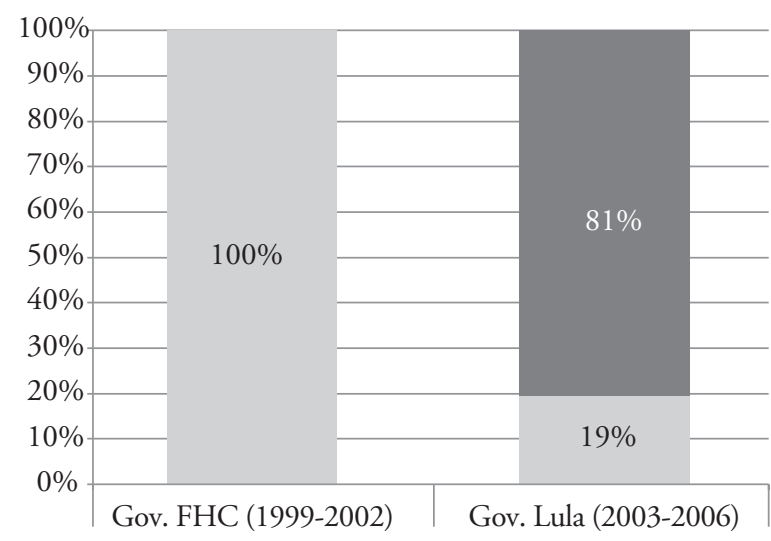

Lula (2003-2006)

FHC (1999-2002)

Base: 195 ADIns, com liminar (mas não mérito) julgada entre janeiro de 1999 e dezembro de 2006.

Em relação à resposta que o STF deu às demandas que recebeu no período, em termos de decisão final, notamos um Supremo respondendo de forma mais "positiva" no primeiro governo Lula do que no segundo governo FHC - por resposta positiva entendemos o acolhimento e deferimento, total ou parcial, da demanda. O percentual de ações não conhecidas também foi maior no governo FHC se comparado ao governo Lula (Gráfico 7).

De maneira geral, podemos afirmar que do total de ADIns com decisão final julgada durante o segundo governo FHC, 30\% foram deferidas (total ou parcialmente) e no primeiro governo Lula, do total de ADIns com decisão final julgada, $46 \%$ foram deferidas (total ou parcialmente). Fazendo um teste estatístico simples é possível afirmar que há associação entre governo e resultado da decisão, ${ }^{6}$ ou seja, o Supremo respondeu às demandas de forma muito mais positiva no governo Lula do que no governo FHC.

\section{Gráfico 7 \\ Resultado da Decisão Final de acordo com o Governo em que foi julgada a Ação (valores em \%)}

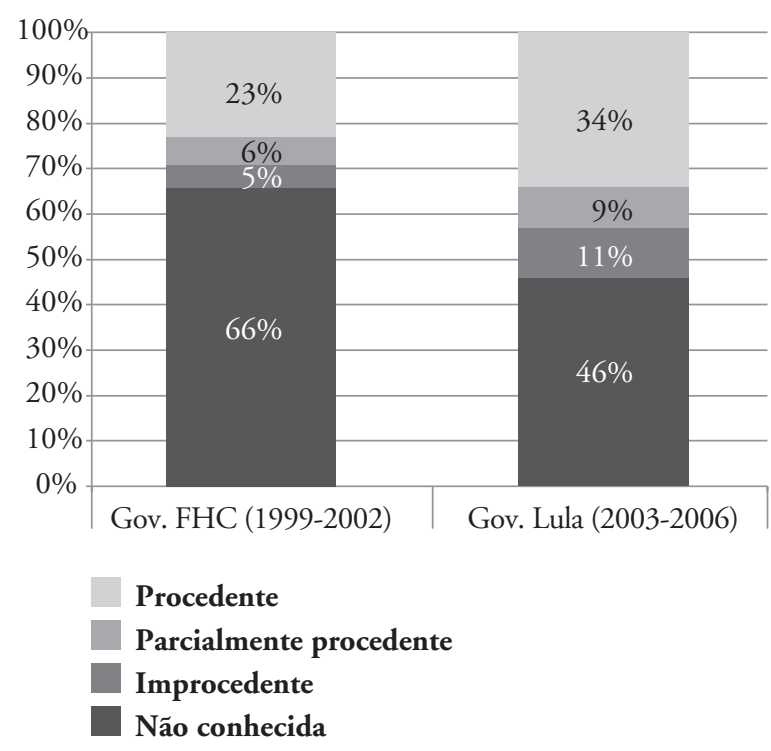

Base: 1.277 ADIns, com decisão final julgada entre janeiro de 1999 e dezembro de 2006.

E qual a razão para essa diferença no padrão de resposta? Precisamos considerar, como atenta Taylor (2008), para o contexto do pedido e do momento da decisão (aqui traduzido pelas variáveis: demandantes, demandados, composição do tribunal) e para o conteúdo das demandas (aqui traduzido pelas variáveis: origem da norma e objeto da ação).

\section{Perfil das demandas e dos demandantes}

A origem das normas questionadas não varia muito entre governos, havendo em ambos o predomínio das questões estaduais. Isso corrobora o que Vianna et al. já atentavam em 1999, ou seja, há uma singularidade da judicialização da política no Brasil tendo em vista que mais do que um recurso das minorias contra as maiorias parlamentares, a judicialização da política no país revela-se muito próxima ao uso do Supremo como um Conselho de Estado, em que se discutem questões federativas (Gráfico 8). 
Gráfico 8

Origem da Norma Questionada de acordo com o Governo em que foi julgada a Ação (valores em \%)

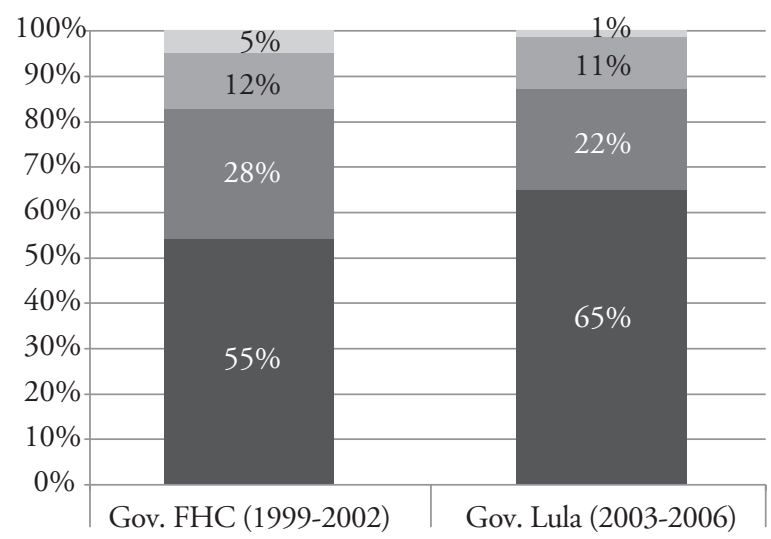

Municipal
Judiciário/Conselhos
Federal
Estadual

Base: 1.277 ADIns, com decisão final julgada entre janeiro de 1999 e dezembro de 2006.
Os legislativos estaduais são os maiores requeridos, seguidos de normas e açôes dos governos estaduais como um todo. No período de 1988 a 2005, Vianna et al. (2007) contabilizam que $55 \%$ do total de ADIns ajuizadas no STF foram contra normas produzidas pelos legislativos estaduais.

O alto índice de litigação contra normas dos legislativos estaduais aponta para a existência de problemas na formação da vontade política local, seja porque o executivo não detém maioria nas assembléias estaduais, seja porque essas instâncias de poder, expostas às pressōes de grupos de interesses particularistas, eventualmente produzem uma legislação casuística e sem escopo universalista. Esse tipo de litigação está orientado, em geral, para a defesa da ordem racional-legal disciplinada pela Constituição, e, como tal, deságua no STF, emprestando a essa corte, na prática, o papel de um conselho de Estado (Vianna et al., 2007, p. 50).

\section{Gráfico 9}

Requerido de acordo com o Governo em que foi julgada a Ação (valores em \%)

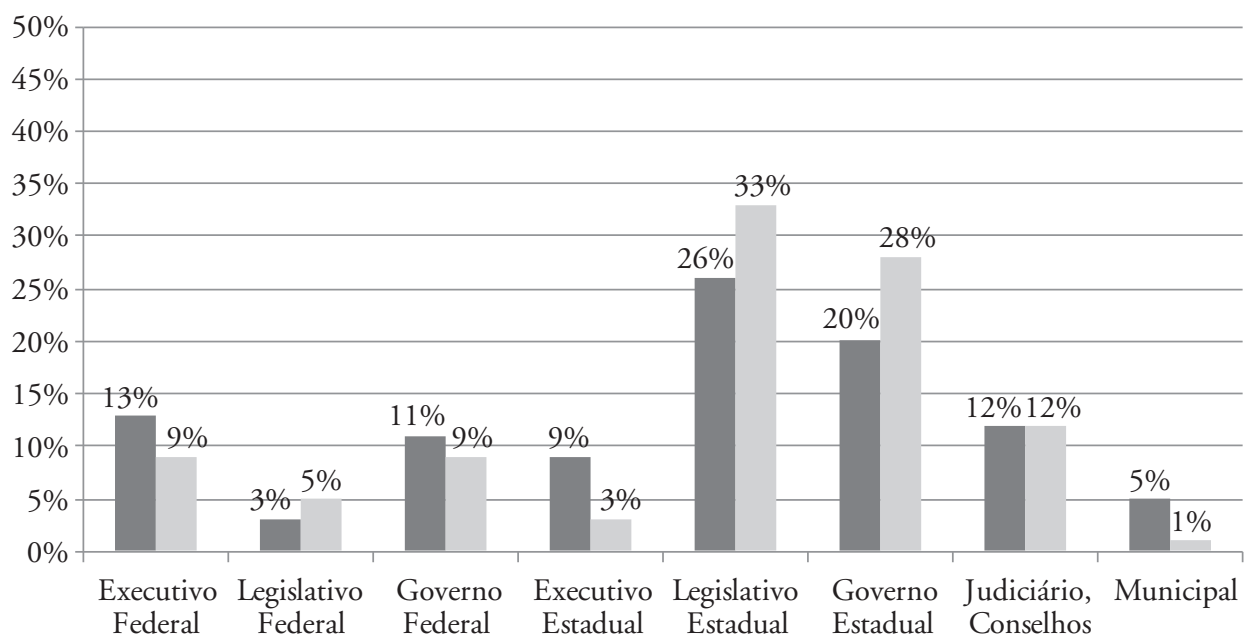

Gov. FHC (1999-2002)

Gov. Lula (2003-2006)

Base: 1.277 ADIns , com decisão final julgada entre janeiro de 1999 e dezembro de 2006. 
Embora não haja diferença entre os governos em termos do predomínio de normas estaduais, há diferença em termos da ênfase: no governo Lula as normas estaduais cresceram ainda mais no universo de açôes julgadas - o que acompanha e reflete bem o perfil de ações que deram entrada.

No mesmo sentido dos achados de Taylor e Da Ros (2008), os dados indicam que houve uma queda na utilização do Supremo pelos partidos políticos e o aumento de utilização pelos governadores e pelo procurador-geral da República. Assim, o Supremo vai transitando de uma arena de disputas políticas no governo FHC para se constituir com ainda mais força em um tribunal da federação no governo Lula (Gráfico 9).

O instrumento da $\mathrm{ADI}$ se mostrará altamente sensível às mudanças nas políticas de governo: a esquerda, que recorria a ele com muita frequência no período FHC, diminui significativamente o seu uso; em especial o Partido dos Trabalhadores, um antigo campeão - como era de se esperar - não elaborará nenhuma
ADI contra normas federais no governo Lula (Taylor e Da Ros, 2008, p. 43).

A ADIn é sensível às mudanças nas políticas de governo em termos das partes envolvidas, mas é pouco sensível em termos de temáticas julgadas embora a agenda política entre um governo e outro tenha mudado, em termos da temática das normas julgadas no STF não houve grande variação - há um predomínio absoluto das questôes ligadas à administração pública, seguidas especificamente da administração da justiça, imprimindo à corte, conforme classifica Vianna et al. (1999, 2007), um forte caráter de racionalizador da administração pública (Gráfico 10).

Não há diferença significativa entre os temas julgados nos dois governos, mas quando olhamos nos temas das ações julgadas conforme o governo de entrada, notamos pequenas diferenças, embora a predominância seja a mesma: administração pública, administração da justiça e questôes econômico-tributárias.

As ações classificadas como pertencentes à temática "administração pública" tratam de aspectos

Gráfico 10

Requerente $^{7}$ de acordo com o Governo em que foi julgada a Ação (valores em \%)

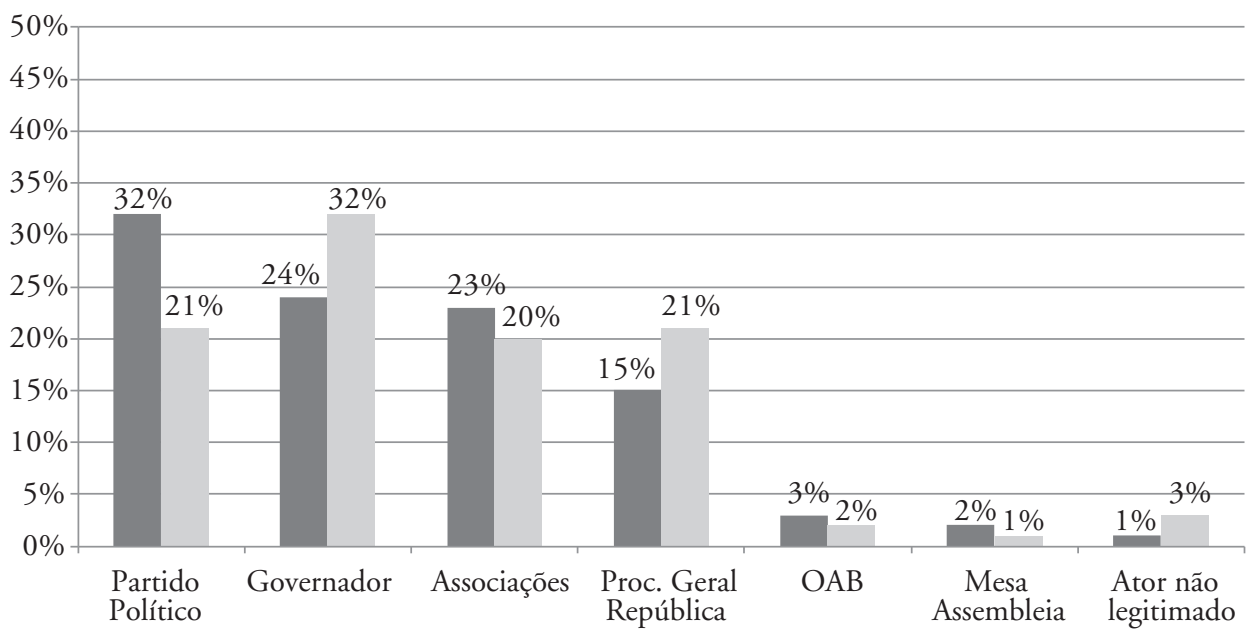

Gov. FHC (1999-2002)

Gov. Lula (2003-2006)

Base: 1.277 ADIns, com decisão final julgada entre janeiro de 1999 e dezembro de 2006. 
ligados à organização e ao funcionamento do Estado, desde questōes relativas ao serviço público no âmbito dos Poderes Executivo e Legislativo (ingresso, remuneração, promoção, aposentadoria etc.), à organização da carreira dos militares e pagamentos de pensão, organização da carreira de funcionários de autarquias, até questōes ligadas ao sistema federativo e à separação de poderes. Também foram classificadas como administração pública questôes relativas à nomeação dos membros dos Tribunais de Conta dos Estados e da União.

Optamos por separar de administração pública as questōes relativas à organização dos tribunais e das carreiras do Judiciário e também das demais carreiras públicas ligadas às profissões jurídicas e ao sistema de justiça (advocacia e defensoria pública, procuradorias, ministério público e polícia civil). Estas questôes foram classificadas sob a categoria "administração da justiça".

Mais da metade das ADIns julgadas pelo Supremo nos dois governos foi com o intuito de disciplinar o funcionamento do Estado e da Justiça. O Estado foi o grande "cliente" do Supremo em termos de controle concentrado via ADIn.

Em terceiro lugar figuram açōes ligadas a questôes econômico-tributárias, agregando assuntos relativos à regulação da economia, como as políticas monetária, salarial, de preços e tributária, e questôes relativas aos processos de privatização. Aqui estão principalmente disputas em relação à cobrança de ICMS entre Estados.

Questôes relativas à sociedade civil vêm em seguida. Esta é uma categoria ampla, reunindo assuntos relativos às relações entre particulares e questões ligadas ao meio ambiente e à liberdade de expressão. As questões ligadas ao mundo do trabalho referem-se à regulamentação de relações trabalhistas na iniciativa privada.

E por fim estão as disputas político-partidárias, abrangendo questóes relativas ao processo eleitoral, propaganda eleitoral e utilização de urnas eletrônicas para "treinar" eleitores, divulgação de pesquisas eleitorais, coligaçōes partidárias, ações rescisórias eleitorais, o funcionamento e a organização dos partidos políticos etc. (Gráfico 11).

Quando comparamos o tema das açóes com a origem da norma, notamos que há diferença no acionamento do Supremo para julgamento das normas de origem federal nos dois governos: no governo FHC elas são predominantemente relativas à questão da administração pública e no governo Lula ganha força o julgamento de questôes econômico-tributárias (Tabela 1).

\section{Gráfico 11}

Classe Temática de acordo com o Governo em que foi julgada a Ação (valores em \%)

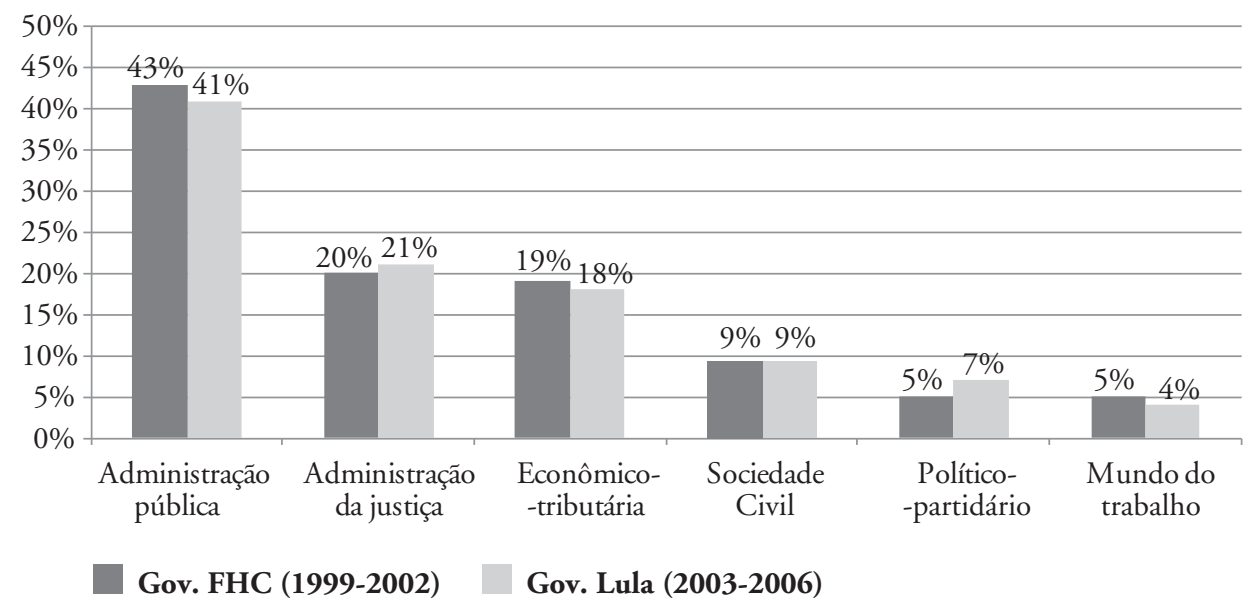

Base: 1.277 ADIns, com decisão final julgada entre janeiro de 1999 e dezembro de 2006. 
E há também uma mudança de orientação quanto à decisão - em termos de decisão por tema, no governo FHC há uma proporção maior de ações não conhecidas em sociedade civil, mundo do trabalho e econômico-tributária. Já no governo Lula essas ações são algumas das mais deferidas. Essa mudança de orientação suscita a questão sobre se tal mudança teria relação com a alteração de composição do tribunal (Tabela 2 ).
A mudança de orientação das decisões aparece também quando comparamos o resultado da decisão com a origem da norma questionada (Tabela 3). Enquanto no governo FHC apenas 5\% das normas federais foram julgadas procedentes, no governo Lula esse percentual passou para $14 \%{ }^{8}$

Esses dados, juntamente com a colocação de Taylor de que os governos na maioria das vezes atuam de forma constitucional, enfraquecem o

Tabela 1

Classe Temática de acordo com Origem da Norma Questionada, por Governo de Decisão

\begin{tabular}{llllll|lllll}
\hline \multirow{2}{*}{$\begin{array}{l}\text { Classe Temática/ } \\
\text { Origem }\end{array}$} & \multicolumn{5}{c|}{ Gov. FHC (1999-2002) } & \multicolumn{5}{c}{ Gov. Lula (2003-2006) } \\
\cline { 2 - 11 } & $\begin{array}{l}\text { Judiciário/ } \\
\text { Conselho }\end{array}$ & Federal Estadual & Municipal & Total & $\begin{array}{l}\text { Judiciário/ } \\
\text { Conselho }\end{array}$ & Federal & Estadual & Municipal & Total \\
\hline Adm. pública & $7 \%$ & $36 \%$ & $59 \%$ & $45 \%$ & $45 \%$ & $6 \%$ & $27 \%$ & $55 \%$ & $60 \%$ & $43 \%$ \\
\hline Adm. da justiça & $63 \%$ & $12 \%$ & $17 \%$ & - & $20 \%$ & $64 \%$ & $9 \%$ & $19 \%$ & - & $22 \%$ \\
\hline Político-partidária & $28 \%$ & $4 \%$ & - & $3 \%$ & $5 \%$ & $28 \%$ & $9 \%$ & $2 \%$ & - & $7 \%$ \\
\hline $\begin{array}{l}\text { Econômico- } \\
\text { tributária }\end{array}$ & - & $30 \%$ & $17 \%$ & $38 \%$ & $19 \%$ & $2 \%$ & $42 \%$ & $13 \%$ & $30 \%$ & $19 \%$ \\
\hline Mundo do trabalho & $1 \%$ & $10 \%$ & $1 \%$ & $3 \%$ & $4 \%$ & - & $9 \%$ & $1 \%$ & - & $3 \%$ \\
\hline Sociedade Civil & $1 \%$ & $8 \%$ & $6 \%$ & $10 \%$ & $6 \%$ & - & $4 \%$ & $9 \%$ & $10 \%$ & $7 \%$ \\
\hline Total (N) & $\mathbf{7 2}$ & $\mathbf{1 5 5}$ & $\mathbf{3 1 7}$ & $\mathbf{2 9}$ & $\mathbf{5 7 3}$ & $\mathbf{8 5}$ & $\mathbf{1 6 0}$ & $\mathbf{4 4 9}$ & $\mathbf{1 0}$ & $\mathbf{7 0 4}$ \\
\hline
\end{tabular}

Base: 1.277 ADIns, com decisão final julgada entre janeiro de 1999 e dezembro de 2006.

Fonte: Base de dados própria elaborada a partir dos acórdãos da ADIns.

Tabela 2

Resultado da Decisão de acordo com Temática da Norma Questionada, por Governo de Decisão

\begin{tabular}{llllllll}
\hline \multirow{2}{*}{$\begin{array}{l}\text { Governo } \\
\text { Decisão }\end{array}$} & \multirow{2}{*}{\begin{tabular}{l} 
Classe Temática \\
\cline { 3 - 8 }
\end{tabular}} & $\begin{array}{l}\text { Resultado decisão } \\
\text { pública }\end{array}$ & $\begin{array}{l}\text { Político- } \\
\text {-partidária }\end{array}$ & $\begin{array}{l}\text { Econômico- } \\
\text {-tributária }\end{array}$ & $\begin{array}{l}\text { Mundo do } \\
\text { trabalho }\end{array}$ & $\begin{array}{l}\text { Administração } \\
\text { da justiça }\end{array}$ & $\begin{array}{l}\text { Sociedade } \\
\text { Civil }\end{array}$ \\
\hline \multirow{3}{*}{ FHC } & Procedente (total/parcial) & $38 \%$ & $4 \%$ & $10 \%$ & $14 \%$ & $39 \%$ & $19 \%$ \\
\cline { 2 - 8 } & Improcedente & $3 \%$ & $15 \%$ & $6 \%$ & & $6 \%$ & $3 \%$ \\
\cline { 2 - 8 } & Não conhecida & $58 \%$ & $81 \%$ & $84 \%$ & $86 \%$ & $55 \%$ & $78 \%$ \\
\cline { 2 - 8 } & Total (N) & $\mathbf{2 6 0}$ & $\mathbf{2 7}$ & $\mathbf{1 1 1}$ & $\mathbf{2 1}$ & $\mathbf{1 1 7}$ & $\mathbf{3 7}$ \\
\hline \multirow{3}{*}{ Lula } & Procedente (total/parcial) & $54 \%$ & $35 \%$ & $23 \%$ & $29 \%$ & $39 \%$ & $56 \%$ \\
\cline { 2 - 8 } & Improcedente & $9 \%$ & $14 \%$ & $11 \%$ & $14 \%$ & $9 \%$ & $18 \%$ \\
\cline { 2 - 8 } & Não conhecida & $37 \%$ & $51 \%$ & $66 \%$ & $57 \%$ & $51 \%$ & $26 \%$ \\
\cline { 2 - 8 } & Total $(\mathbf{N})$ & $\mathbf{3 0 0}$ & $\mathbf{4 9}$ & $\mathbf{1 3 2}$ & $\mathbf{2 1}$ & $\mathbf{1 5 2}$ & $\mathbf{5 0}$ \\
\hline
\end{tabular}

Base: 1.277 ADIns, com decisão final julgada entre janeiro de 1999 e dezembro de 2006.

Fonte: Base de dados própria elaborada a partir dos acórdãos da ADIns. 
Tabela 3

Resultado da Decisão de acordo com a Origem da Norma Questionada,
por Governo de Decisão

\begin{tabular}{llllll}
\hline \multirow{2}{*}{ Governo Decisão } & Resultado decisão & \multicolumn{3}{c}{ Origem } \\
\cline { 3 - 6 } & & Jud/ Cons & Federal & Estadual & Municipal \\
\hline \multirow{3}{*}{ FHC } & Procedente (total/parcial) & $29 \%$ & $5 \%$ & $44 \%$ & - \\
\cline { 2 - 6 } & Improcedente & $6 \%$ & $8 \%$ & $3 \%$ & - \\
\cline { 2 - 6 } & Não conhecida & $65 \%$ & $86 \%$ & $53 \%$ & $100 \%$ \\
\cline { 2 - 6 } & Total (N) & $\mathbf{7 2}$ & $\mathbf{1 5 5}$ & $\mathbf{3 1 7}$ & $\mathbf{2 9}$ \\
\hline \multirow{3}{*}{ Lula } & Procedente (total/parcial) & $28 \%$ & $14 \%$ & $57 \%$ & - \\
\cline { 2 - 6 } & Improcedente & $6 \%$ & $17 \%$ & $10 \%$ & - \\
\cline { 2 - 6 } & Não conhecida & $66 \%$ & $69 \%$ & $33 \%$ & $100 \%$ \\
\cline { 2 - 6 } & Total (N) & $\mathbf{8 5}$ & $\mathbf{1 6 0}$ & $\mathbf{4 4 9}$ & $\mathbf{1 0}$ \\
\hline
\end{tabular}

Base: 1.277 ADIns, com decisão final julgada entre janeiro de 1999 e dezembro de 2006.

Fonte: Base de dados própria elaborada a partir dos acórdãos da ADIns.

argumento de Maranhão (2003) de que haveria sempre subserviência dos ministros ao governo que os nomeou - para a autora, os ministros votariam consistentemente com as preferências do governo em que foram nomeados.

Uma mudança de $5 \%$ para $14 \%$ de normas federais derrubadas num governo em que o Presidente tem maioria no tribunal coloca em xeque a força dessa afirmação. É claro que pelo que observamos há associação entre governo e resultado das decisões, mas não é uma associação tão direta visto que há diferenças de acordo com o governo em questão. E é preciso considerar, como faremos na sequência, se o governo de decisão se mantém significativo nessa relação quando controlado pela presença de outras variáveis.

Mas antes disso, vamos observar o comportamento de decisão do tribunal quando a norma em questão é de origem federal, ou seja, qual a resposta que o Supremo deu às ADIns de interesse do governo federal. É preciso ter em mente que nem sempre uma norma de origem federal corresponde à preferência presidencial, mas é presumível que na grande maioria das vezes ela corresponda à preferência da coalizão governante.

\section{ADIns que questionam diplomas federais}

Se considerarmos junto com grande parte da literatura e da opinião pública que presidentes nomeiam ministros esperando que eles defendam seus interesses de governo no Supremo, esperamos encontrar uma situação em que o Supremo vote consistentemente com as preferências dos presidentes e não contrariem tais interesses (Pacheco, 2008, p. 81).

Notamos que há uma mudança no padrão de resposta entre os dois governos analisados. Durante o governo Lula há uma resposta mais "positiva" (por resposta positiva entenda-se favorável à procedência ou deferimento da ação) por parte do Supremo às demandas ouvidas. E quando comparamos o padrão de resposta às questôes envolvendo normas federais com as mudanças na composição do Supremo, notamos que há indícios de associação - as composiçôes finais do tribunal tendem a deferir proporcionalmente mais ações do que as iniciais. Ou seja, o Supremo nomeado por Lula tendeu a contrariar proporcionalmente mais o governo.

A agenda temática também sofreu alteraçōes entre os governos, havendo no governo Lula um enfo- 
Tabela 4

Resultado da Decisão Final da Ação de acordo com Governo de Decisão, Controlado pelo Governo em que deu Entrada

\begin{tabular}{|c|c|c|c|c|c|}
\hline \multirow{2}{*}{$\begin{array}{l}\text { Governo de } \\
\text { decisão }\end{array}$} & \multirow{2}{*}{$\begin{array}{l}\text { Governo de ingresso } \\
\text { da ação }\end{array}$} & \multicolumn{3}{|c|}{ Resultado da decisão } & \multirow{2}{*}{$\begin{array}{l}\text { Total } \\
(\mathrm{N})\end{array}$} \\
\hline & & Náo conhecida & Improcedente & $\begin{array}{l}\text { Procedente } \\
\text { (parcial/total) }\end{array}$ & \\
\hline \multirow{3}{*}{ FHC } & Pré-1995 & $95 \%$ & & $5 \%$ & 21 \\
\hline & FHC1 & $91 \%$ & $7 \%$ & $2 \%$ & 100 \\
\hline & FHC2 & $68 \%$ & $18 \%$ & $15 \%$ & 34 \\
\hline \multirow{4}{*}{ Lula } & Pré-1995 & $63 \%$ & $38 \%$ & & 8 \\
\hline & FHC1 & $72 \%$ & $21 \%$ & $7 \%$ & 29 \\
\hline & FHC2 & $70 \%$ & $15 \%$ & $16 \%$ & 89 \\
\hline & Lula & $68 \%$ & $15 \%$ & $18 \%$ & 34 \\
\hline
\end{tabular}

Base: 315 ADIns, com decisão final julgada entre janeiro de 1999 e dezembro de 2006, cuja origem da norma é federal. Fonte: Base de dados própria elaborada a partir dos acórdãos da ADIns.

Tabela 5

Resultado da Decisão Final das ADIns de acordo com Composição do Tribunal

\begin{tabular}{llllllll}
\hline \multirow{2}{*}{ Resultado } & \multicolumn{7}{c}{ Corte (composição: ministros) } \\
\cline { 2 - 8 } & $\mathbf{1}$ & $\mathbf{2}$ & $\mathbf{3}$ & $\mathbf{4}$ & $\mathbf{5}$ & $\mathbf{6}$ & 7 \\
\hline Deferido & $4 \%$ & $3 \%$ & $14 \%$ & $3 \%$ & $13 \%$ & $8 \%$ & $35 \%$ \\
\hline Indeferido & $3 \%$ & $3 \%$ & $33 \%$ & $10 \%$ & $14 \%$ & $42 \%$ & $19 \%$ \\
\hline Não Conhecido & $93 \%$ & $94 \%$ & $53 \%$ & $87 \%$ & $72 \%$ & $50 \%$ & $46 \%$ \\
\hline Total (N) & 71 & 62 & 36 & 39 & 69 & 12 & 26 \\
\hline
\end{tabular}

Base: 315 ADIns, com decisão final julgada entre janeiro de 1999 e dezembro de 2006, cuja origem da norma é federal. Fonte: Base de dados própria elaborada a partir dos acórdãos da ADIns.

que maior nas questôes econômico-tributárias - política de reajuste de salário mínimo, concessão para exploração de recursos naturais, imposto de renda e CPMF foram alguns dos temas de destaque.

No governo Lula também aumentou a participação de disputas político-partidárias, com ênfase em temas como fidelidade partidária, regulamentação de propaganda e regulamentação dos partidos políticos.

Há diferença no padrão de resposta por área temática. Nos dois governos as disputas políticopartidárias tendem a ser mais deferidas, com des- taque para o governo Lula em que $43 \%$ das ações que versavam sobre esse tema foram julgadas procedentes.

Os dados descritivos do período indicam que o Supremo respondeu de forma mais positiva aos demandantes no governo Lula em comparação ao governo FHC (lembrando que classificamos por resposta positiva a declaração de lei, norma ou diploma inconstitucional). Mas o que acontece quando comparamos o peso relativo que cada uma destas variáveis tem em um único modelo multivariado? 


\section{Gráfico 12}

Classe Temática das Normas Federais de acordo com o

Governo em que Foi Julgada a Ação (valores em \%)

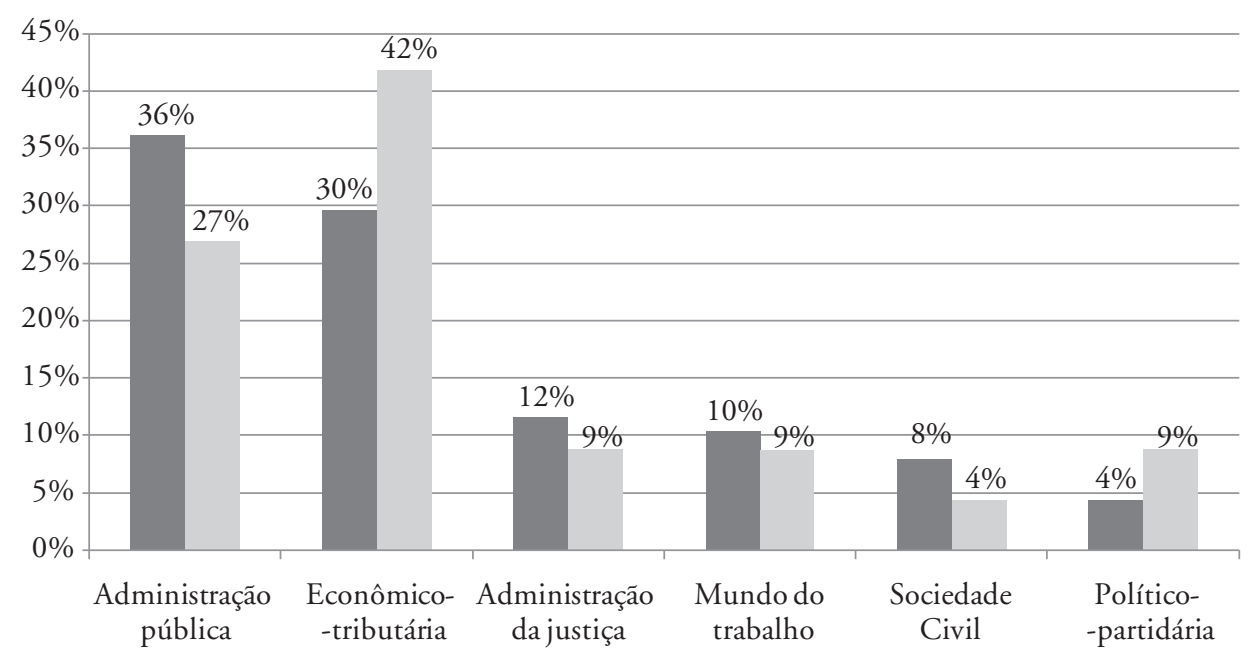

Gov. FHC (1999-2002)

Gov. Lula (2003-2006)

Base: 315 ADIns, com decisão final julgada entre janeiro de 1999 e dezembro de 2006, cuja origem da norma é federal.

\section{Análise multivariada do processo decisório no STF}

O que leva o Supremo a responder positivamente a uma demanda? Qual o impacto da influência do governo quando controlado por outras variáveis, como os demandantes, o tema em questão e a origem da norma? Qual o impacto do perfil dos ministros e das mudanças na composição do tribunal?

Para responder a estes questionamentos optamos por trabalhar com um modelo de regressão logística. A regressão logística permite determinar o efeito que um conjunto de variáveis tem na probabilidade de ocorrência de um evento. No nosso caso, qual a probabilidade do Supremo responder de forma positiva às demandas que chegam até ele via ADIn? De forma mais direta, quais as chances de uma ação ser deferida no mérito? A regressão logística permite determinar o efeito de variáveis individuais na medida em que controla a presença das outras variáveis na relação.
O exponencial do coeficiente mostra a mudança nas chances preditas de um evento ocorrer em relação à possibilidade desse evento não ocorrer. Se o exponencial do coeficiente $[\operatorname{Exp}(B)]$ tem valor igual a um, ele não altera as chances do evento ocorrer; se o valor é maior do que um, ele aumenta as chances do evento ocorrer, e se o valor é menor do que um, diminui as chances do evento ocorrer. Ou seja, quanto mais distante de um, maior seu efeito sobre o evento de interesse (Ver Pampel, 2000; Oliveira, 2008).

Nosso modelo busca identificar as variáveis de maior influência no resultado final das ações de controle de constitucionalidade. Incluímos variáveis relativas tanto à dinâmica interna do tribunal (variáveis internas como composição e proporção de magistrados votando na ação) quanto variáveis relativas à dinâmica externa, ou seja, ao cenário político do momento (variáveis externas, como governo de decisão, tema e partes).

De acordo com os resultados apresentados na Tabela 6, vemos que normas federais têm menores 


\section{Gráfico 13}

\section{Resultado da Decisão de acordo com a Classe Temática das Normas Federais (valores em \%)}

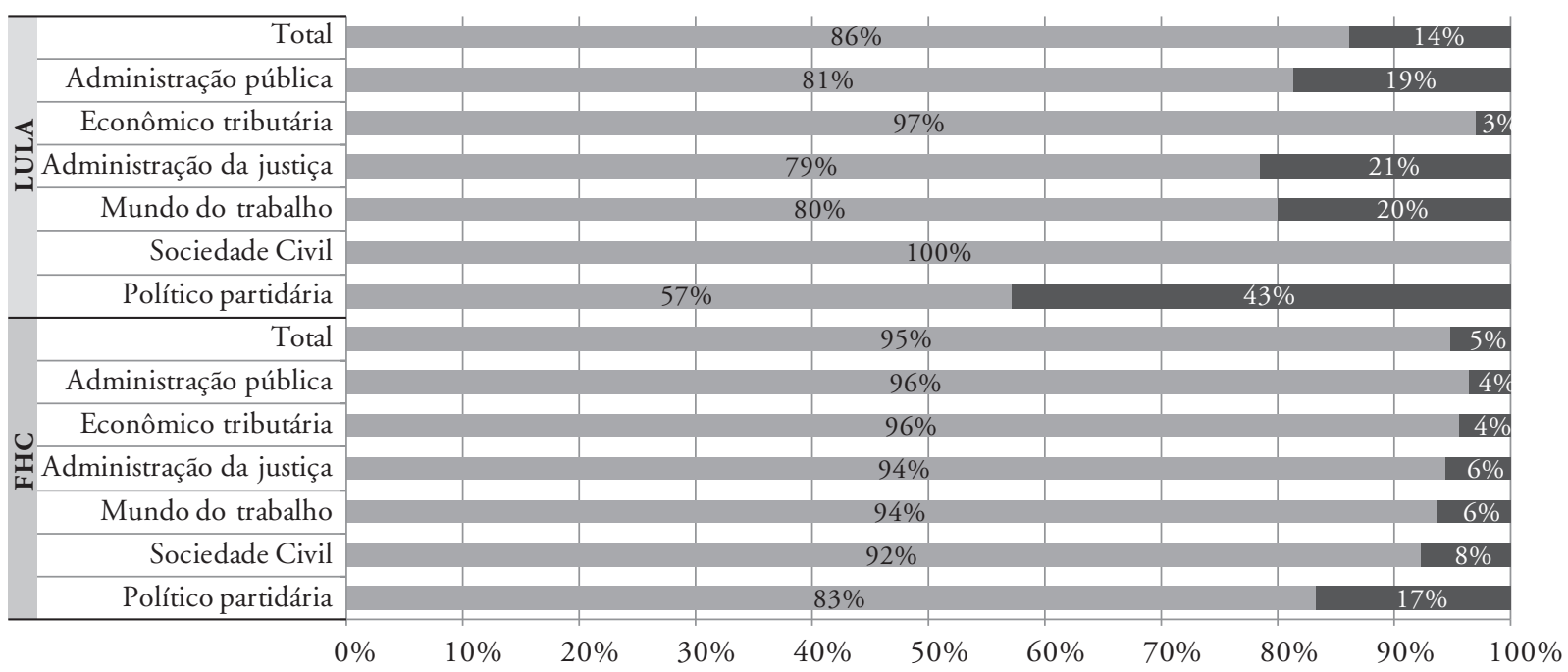

\section{Indeferido Deferido}

Base: 315 ADIns, com decisão final julgada entre janeiro de 1999 e dezembro de 2006, cuja origem da norma é federal.

chances de serem derrubadas via ADIn se comparadas a normas estaduais e a diplomas com origem no Judiciário ou nas agências. E o momento político também tem grande impacto: açôes julgadas no mesmo governo de distribuição também têm proporcionalmente menores chances de serem deferidas.

Utilizando a composição do tribunal como um proxy de variável atitudinal, ou seja, como um indicador de perfil ideológico, notamos que ela exerce um grande peso. Comparando a primeira composição vemos que ela é a mais restritiva quando comparada às demais (com exceção da quarta e quinta). A última é a que proporcionalmente deferiu mais ações, seguida da segunda, da terceira e da sexta.

E confirmamos também que uma maior proporção de magistrados na composição do tribunal, tende a deixar o tribunal um pouco mais restritivo.

Observamos ainda o impacto tanto do tema em questão quanto dos requerentes. O Supremo responde mais positivamente às demandas de governadores e do procurador-geral da República se comparadas às demandas dos partidos políticos.
E responde mais positivamente às demandas sobre o mundo do trabalho quando comparadas às demandas ligadas ao tema da administração pública. E responde de forma mais restritiva quando o assunto é econômico-tributário ou relacionado com a administração da justiça, comparativamente à administração pública.

$\mathrm{O}$ voto do relator não foi considerado nesse primeiro modelo, pois aqui mantivemos também as açōes decididas de forma monocrática. Eliminando as ADINs com decisão monocrática (585 açôes) e inserindo o voto do relator como uma das variáveis preditivas, temos que sozinho o voto do relator dá conta de explicar a quase totalidade da variação no resultado da decisão.

$\mathrm{O}$ voto do relator varia quase perfeitamente com a variável alvo - o coeficiente de correlação entre voto do relator e resultado final do mérito é de 0,987 . Em apenas 6 das 692 ações julgadas no período considerado, o voto do relator foi diferente do resultado final da decisão, ou seja, em $99 \%$ dos casos o voto do relator é igual à decisão final da 


\section{Tabela 6}

Regressão Logística Considerando como Alvo a Variável Decisão do Mérito (deferida parcial ou total)

\begin{tabular}{llll} 
& Coeficiente B & Sig. & Exponencial Exp(B) \\
\hline Origem diploma: federal & $-1,32$ & 0,00 & 0,27 \\
\hline Ação julgada no mesmo governo de distribuição & $-0,86$ & 0,00 & 0,42 \\
\hline Proporção de magistrados no tribunal & $-0,02$ & 0,01 & 0,98 \\
\hline Governo decisão: FHC & $-0,05$ & 0,88 & 0,95 \\
\hline Composição 1 & Categoria de referência & \\
\hline Composição 2 & 1,20 & 0,00 & 3,31 \\
\hline Composição 3 & 1,14 & 0,00 & 3,11 \\
\hline Composição 4 & 0,45 & 0,18 & 1,57 \\
\hline Composição 5 & 0,57 & 0,08 & 1,76 \\
\hline Composição 6 & 0,96 & 0,04 & 2,61 \\
\hline Composição 7 & 1,77 & 0,00 & 5,85 \\
\hline Tema: Administração pública & Categoria de referência & \\
\hline Tema: questão político-partidária & $-0,31$ & 0,37 & 0,74 \\
\hline Tema: econômico-tributária & $-1,45$ & 0,00 & 0,24 \\
\hline Tema: mundo do trabalho & 0,88 & 0,02 & 2,41 \\
\hline Tema: administração da justiça & $-0,37$ & 0,04 & 0,69 \\
\hline Tema: sociedade civil & 0,36 & 0,15 & 1,43 \\
\hline Autor: partido político & Categoria de referência & \\
\hline Autor: procurador-geral & 1,39 & 0,00 & 4,02 \\
\hline Autor: governador & 1,55 & 0,00 & 4,72 \\
\hline Autor: mesa assembleia & $-20,04$ & 1,00 & 0,00 \\
\hline Autor: associação/sindicato & $-0,20$ & 0,38 & 0,82 \\
\hline Autor: OAB & 0,72 & 0,09 & 2,06 \\
\hline Pagen & & & \\
\hline
\end{tabular}

Nagelkerke R Square $=0,44$

Número de observações: 1.277

corte. E como o relator é o primeiro a votar, isso implica em que conhecer a direção desse voto é saber o resultado final em $99 \%$ das vezes.

A única variável que continua significativa para explicar o resultado da decisão junto com o voto do relator é a proporção de magistrados no tribunal quanto maior a proporção de ministros magistrados em uma decisão, menor a chance de a ação ser deferida no mérito. (Tabela 6.1)

De acordo com o Regimento Interno do STF, no artigo 21, inciso $\mathrm{X}$, cabe ao relator "pedir dia para julgamento dos feitos nos quais estiver habilitado a proferir voto, ou passá-los ao Revisor, com o relatório, se for o caso" (Regimento interno, 2010, p. 35). Ou seja, o grande sucesso do relator pode ser um indicativo de que há negociaçōes nos bastidores do Supremo e um tema só entraria em pauta na agenda de votação quando o relator entende que tem maioria suficiente para aderir a sua orientação.

O grande peso que o voto do relator tem na decisão suscita ainda outros questionamentos, es- 
Tabela 6.1

Regressão Logística Considerando como Alvo a Variável Decisão do Mérito (deferida parcial ou total), Excluindo Decisões Monocráticas

\begin{tabular}{llll} 
& Coeficiente B & Sig. & Exponencial Exp(B) \\
\hline Origem diploma: federal & $-0,04$ & 0,98 & 0,96 \\
\hline Ação julgada no mesmo governo de distribuição & $-1,37$ & 0,30 & 0,26 \\
\hline Proporção de magistrados no tribunal & $-0,12$ & 0,07 & 0,89 \\
\hline Voto relator (deferido) & 11,77 & 0,00 & 129022,90 \\
\hline Composição 1 & Categoria de referência & \\
\hline Composição 2 & 3,57 & 0,24 & 35,54 \\
\hline Composição 3 & 0,45 & 0,87 & 1,57 \\
\hline Composição 4 & $-1,24$ & 0,63 & 0,29 \\
\hline Composição 5 & $-0,52$ & 0,82 & 0,60 \\
\hline Composição 6 & $-0,48$ & 0,89 & 0,62 \\
\hline Composição 7 & $-1,82$ & 0,43 & 0,16 \\
\hline Tema: Administração pública & Categoria de referência & \\
\hline Tema: questão político-partidária & 0,11 & 0,97 & 1,11 \\
\hline Tema: econômico-tributária & $-0,63$ & 0,76 & 0,54 \\
\hline Tema: mundo do trabalho & 0,11 & 0,98 & 1,12 \\
\hline Tema: administração da justiça & $-0,02$ & 0,99 & 0,98 \\
\hline Tema: sociedade civil & $-2,25$ & 0,21 & 0,11 \\
\hline Autor: partido político & Categoria de referência & \\
\hline Autor: procurador-geral & 0,91 & 0,66 & 2,49 \\
\hline Autor: governador & 1,53 & 0,43 & 4,61 \\
\hline Autor: mesa assembleia & $-16,07$ & 1,00 & 0,01 \\
\hline Autor: associação/sindicato & $-0,84$ & 0,68 & 0,43 \\
\hline Autor: OAB & 0,02 & 1,00 & 1,02 \\
\hline Pagen & & & \\
\hline
\end{tabular}

Nagelkerke R Square $=0,98$

Número de observações: 692

pecialmente relativos ao motivo de tamanha relevância. O relator é escolhido aleatoriamente e não há padrão de maior ou menor sucesso do relator de acordo com tema, data, partes etc. Outra possível explicação, além da barganha e negociação de "bastidores", seria a elevada carga de trabalho, o que faz com que os ministros adiram ao voto do relator com maior frequência.

Em artigo no jornal $O$ Estado de S. Paulo, Oscar Vilhena Vieira (2010) relatou um caso interessante sobre o volume de trabalho do Supremo:
[...] o problema do supremo brasileiro é que os ministros decidem muito, não pouco. Não há tribunal constitucional no mundo que tome mais decisóes que o brasileiro. Em recente seminário na África do Sul, ao apresentar números do supremo, percebi um ar de ceticismo na audiência. Não demorou muito para que o juiz Jacoob, proeminente membro da Corte Constitucional sul-africana, gentilmente me interrompesse: "caro Oscar os seus números são inverossímeis; 115 mil casos ao ano signifi- 
ca que, se a corte trabalhasse 240 dias por ano, estaria decidindo 479 casos por dia, o que é mais do que nossa corte julgou em toda sua existência. Isso não me parece possível”. Expliquei então que mais de $90 \%$ das decisões do tribunal eram tomadas monocraticamente e segui minha apresentação. Logo o juiz Jacoob me interrompeu com sua indefectível matemática: "dividindo o total de casos por 11 juízes, isto daria mais de 10 mil casos por ano, por juiz, o que significa cerca de 1 caso a cada 12 minutos. Impossível!”.

\section{Considerações finais}

Os dados analisados aqui permitem concluir que o Supremo Tribunal Federal, ao contrário do que aponta grande parte da literatura, não foi tão parcimonioso em sua atuação no período considerado.

O STF deferiu $37 \%$ das ações decididas no período. No segundo governo FHC o Supremo invalidou $29 \%$ das normas questionadas e no primeiro governo Lula esse percentual saltou para $43 \%$. E considerando apenas as normas federais, temos que das questôes de interesse do segundo governo FHC julgadas durante o próprio governo, $15 \%$ foram decididas contrariamente ao governo e no primeiro governo Lula essa proporção foi um pouco maior, $18 \%$.

O tribunal respondeu de forma mais positiva aos requerentes no primeiro governo Lula quando comparado ao segundo governo FHC. Há diferença na resposta do Supremo entre os dois governos, mas essa diferença deixa de ser significativa quando controlamos por outras variáveis: especialmente a composição do tribunal, a origem da norma, o tema de que trata e os autores destas ações. E confirmamos também que quanto maior a proporção de magistrados na composição do tribunal, mais contido e restritivo ele tende a ser quanto a sua atuação.

Outro ponto de destaque é que mais do que o governo em questão, o que influencia as decisões é o timing de julgamento, ou seja, as ações julgadas no mesmo governo de origem das normas (governo de distribuição) têm proporcionalmente chances menores de serem deferidas. É importante notar também que no segundo governo FHC, comparado ao primeiro governo Lula, foi muito maior o não conhecimento de ações - o que pode ser pensado como uma estratégia formalista para evitar decidir, ou seja, uma estratégia de autocontenção (ver Barroso, 2009).

Esses dois pontos em conjunto são de extrema importância para entender o processo decisório no STF, pois apesar de o tribunal não ter controle direto sobre o que chega até ele (uma vez que o tribual é reativo, só decidindo quando acionado), e de não dispor de um instrumento como a political question doctrine (doutrina pela qual a Suprema Corte norte-americana pode se abster de decidir uma questão em razão de sua natureza inerentemente política), o Supremo exerce grande controle sobre a formação de sua agenda decisória com base na definição dos tempos da pauta (quando o tema será levado a plenário) e por meio de estratégias formalistas para evitar se posicionar sobre questões que possam desgastar sua imagem (não reconhecimento de legitimidade do proponente, pedidos de vista etc.). ${ }^{9}$

Um aspecto importante da discussão sobre a relação do STF com a política que os dados apresentados neste artigo possibilitaram desmitificar foi o de que haveria sempre subserviência dos ministros ao governo que os nomeou. Segundo Maranhão (2003), por exemplo, os ministros do STF sempre votariam consistentemente com as preferências do governo em que foram nomeados. Mas quando olhamos para o período em questão e observamos que no segundo governo FHC (que nomeou três ministros para o tribunal) 5\% das normas federais questionadas foram derrubadas e que no primeiro governo Lula (presidente que nomeou seis ministros para o tribunal) essa proporção saltou para $14 \%$, como explicar esse aumento? E se levarmos em conta a colocação de Kapiszewsky e Taylor (2008) de que os governos na maioria das vezes atuam de forma constitucional, o argumento de subserviência fica ainda mais enfraquecido.

Por fim, um aspecto de suma relevância e que merece maior atenção futura é o peso do relator na determinação do resultado da decisão. Vale dizer, 
em matéria de formação das decisões do STF, o voto do relator importa.

\section{Notas}

1 Judicialização da política pode ser pensada na dimensão institucional da expansão do Poder Judiciário em esferas decisórias de políticas públicas, antes ocupadas tão somente pelos Poderes Executivo e Legislativo e que passam a ser transferidas também para juízes e tribunais, que interferem na determinação da implementação e revisão das regras do jogo democrático (Tate e Vallinder, 1995; Vianna et al. 1999; Maciel e Koerner, 2002). Pode ser pensada também, como coloca Vianna et al. (1999), como uma arena alternativa de resolução de conflitos coletivos e como uma forma de buscar a promoção e a proteção de direitos sociais via judiciário (judicialização das relações sociais).

2 A Constituição de 1988 gerou certa indefinição ao atribuir responsabilidades comuns entre estados e federação para legislar sobre alguns temas, como política social (Kinzo, 1997) - e o STF tem tido papel fundamental em decidir sobre essas políticas.

3 O Poder Judiciário tem competência para a edição de alguns tipos de normas, direcionadas à administração de órgãos do sistema de justiça.

4 Uma hipótese para explicar essa redução do número de ADINs a partir de 2005, seria um possível efeito indireto da promulgação da Emenda Constitucional 45. A partir de mudanças no controle difuso de constitucionalidade, com a adoção da repercussão geral nos recursos extraordinários, é possível que alguns atores tenham alterado e reorganizado sua estratégia de utilização do STF. A EC 45 também introduziu mudanças no controle concentrado, com o efeito vinculante nas decisões de mérito das ADIns (Art. 102, $\$ 2^{\circ}$ ). Para maiores detalhes conferir Falcão, Joaquim, Cerdeira, Pablo C. e Arguelhes, Diego W. (2011). Supremo em Números - O Múltiplo Supremo. Rio de Janeiro: Escola de Direito da Fundação Getulio Vargas do Rio de Janeiro.

5 O STF não possui discricionariedade para decidir se vai ouvir ou não um caso (a Suprema Corte americana, por exemplo, possui o writ of certiorari e também a political question doctrine, instrumento pelo qual pode evitar julgar questões de disputas políticas que poderiam ser resolvidas no congresso), ver Taylor (2008).
6 Pearson Chi-Square = 34,50; DF. $=1 ;$ Sig $=.0,000$.

7 Cite-se como exemplo de associações no período estudado a Confederação Nacional das Profissões Liberais (CNPL); Associação Nacional dos Advogados da União (Anauni); Confederação Nacional da Indústria (CNI); Confederação Nacional dos Estabelecimentos de Ensino (Confenen); Associação dos Membros dos Tribunais de Contas do Brasil (Atricon); Confederação Nacional dos Trabalhadores na Agricultura (Contag); Confederação Nacional de Saúde - Hospitais, Estabelecimentos e Serviços (CNS); Associação dos Notários e Registradores do Brasil (Anoreg/BR); Associação Brasileira dos Extratores e Refinadores de Sal (Abersal); Associação Nacional dos Juízes Classistas da Justiça do Trabalho (Anajucla) etc. Em termos de atores não legitimados temos casos de pessoa física (por exemplo, na ADIn 3204), prefeitos (por exemplo, na ADIn 2171) etc.

8 De maneira geral podemos considerar que há uma associação entre resultado do mérito e origem da norma questionada em todo o período considerado, conforme teste de associação simples - Pearson Chi-Square: 222, 253, 3 df, sig: 0,00.

9 Algumas vezes essas estratégias não são suficientes quando há grande clamor da opinião pública, como no caso da Lei da Ficha Limpa.

\section{BIBLIOGRAFIA}

ARANTES, Rogério Bastos. (1997), Judiciário e política no Brasil. São Paulo, Idesp/Sumaré.

BARROSO, Luís Roberto. (2009), "Judicialização, ativismo judicial e legitimidade democrática”. Revista Eletrônica da OAB, 4: 1-29.

BAUM, Lawrence. (1992), "Membership change and collective voting change in the United States Supreme Court". The Journal of Politics, 54 (1): 3-24

CASTRO, Marcus Faro de. (1997), "O Supremo Tribunal Federal e a judicialização da política”. RBCS, 12 (34): 147-155.

CLAYTON, Cornell W. \& GILLMAN, Howard (1999), Supreme Court decision making: new institutionalist approaches. Chicago, The University of Chicago Press, p. 344.

COLOMBO, Carlos Alberto. (2001), “Os julgamentos do Supremo Tribunal Federal: viola- 
ções aos direitos constitucionais e ilegitimidade". Democracia e Mundo do Trabalho, 3: 119-159.

DAHL, Robert. (1957), "Decisionmaking in a democracy: the Supreme Court as a national policymaker". Journal of Public Law, 6: 279-295.

DWORKIN, Ronald. (1999), O império do direito. São Paulo, Martins Fontes.

EPSTEIN, Lee \& KNIGHT, Jack. (1998), The choices justices make. Washington, CQ Press.

FALCÃO, Joaquim; Cerdeira, Pablo C. \& Arguelhes, Diego W. (2011). Supremo em números o múltiplo Supremo. Rio de Janeiro, Escola de Direito da Fundação Getulio Vargas do Rio de Janeiro.

FELDMAN, Stephen M. (2005), "The rule of law or the rule of politics? Harmonizing the internal and external views of Supreme Court decision making". Law and Social Inquiry, 30 (1): 89-135.

GARAPON, Antoine. (2001), O juiz e a democracia: o guardiāo das promessas. Rio de Janeiro, Revan.

GIBSON, James L. (1983), "From simplicity to complexity: The development of theory in the study of judicial behavior". Political Behavior 5 (1): 7-49.

GROSSMAN, Joel B. (1968), "Dissenting blocs on the Warren Court: a study in judicial role behavior". The Journal of Politics, 30 (4) 10681090.

HELMKE, Gretchen \& STATON, Jeffrey K (2009), "A logic of risky judicial decisions in Latin America". Paper presented on colloquia of law economics and politics.

HURWITZ, Mark S. \& LANIER, Drew Noble. (2004), "I respectfully dissent: consensus, agendas, and policymaking on the U.S. Supreme Court, 1888-1999". The Review of Policy Research, 21 (3): 429-445.

KAPISZEWSKI, Diana \& TAYLOR, Matthew M. (2008), "Doing Courts justice? Studying judicial politics in Latin America". Perspectives on Politics, 6: 741-767.

KINZO, Maria D’Alva Gil (1997). “Governabilidade, estrutura institucional e processo decisório no Brasil". Parcerias Estratégicas, Brasília, 1 (3): 19-37.
MACIEL, Débora Alves \& KOERNER, André (2002). "Sentidos da judicialização da política: duas análises". Lua Nova: Revista de Cultura e Política, 57: 113-133.

MARANHÃO, Tatiana de Pino Albuquerque (2003), Quando o Supremo Tribunal Federal discorda do presidente da República. Dissertação de mestrado, Brasília, UnB, mimeo.

MISHLER, William \& SHEEHAN, Reginald (1993), "The Supreme Court as a countermajoritarian institution? The Impact of Public Opinion on Supreme Court Decisions". American Political Science Review, pp. 87-101.

OLIVEIRA, Vanessa Elias. (2005), "Judiciário e privatizações no Brasil: existe uma judicialização da política?”. Dados, 48 (3): 559-587.

OLIVEIRA, Fabiana Luci (2008), "Justice, professionalism, and politics in the exercise of judicial review by Brazil's Supreme Court". Brazilian Political Science Review, 2: 93-116. . (2011), Justiça, profissionalismo e política: o STF e o controle de constitucionalidade das leis no Brasil. Rio de Janeiro, Editora FGV. PACHECO, Cristina Carvalho. (2006), "O Supremo Tribunal Federal e a reforma do Estado feita pelo governo Fernando Henrique Cardoso: notas introdutórias para uma pesquisa sobre decisão judicial". Trabalho apresentado no $29^{\circ}$ Encontro Anual da Anpocs, Caxambu, pp. 1-21. . (2008), "Os estudos sobre judiciário e política no Brasil pós-1988: uma revisão da literatura”. Pensar, Fortaleza, 13 (1): 75-86.

PAMPEL, Fred C. (2000), Logistc Regression: a primer. Sage Publications, Quantitative Applications in the Social Sciences.

RIBEIRO, Leandro Molhano; ARGUELHES, Diego Werneck \& PEIXOTO, Vitor. (2009), "Processo decisório, Judiciário e políticas públicas". Trabalho apresentado no $33^{\circ}$ Encontro da Anpocs.

SADEK, Maria Tereza Aina (2011), "O Judiciário e a arena pública”, in Lourdes Sola e Maria Rita Loureiro, Democracia, mercado e Estado: o B de Brics, Rio de Janeiro, Editora FGV.

SEGAL, Jeffrey \& SPAETH, Harold. (2002), The Supreme Court and the attitudinal model revisited. Cambridge: Cambridge University Press. 
ULMER, Sidney. (1965), "Toward a theory of sub-group formation in the United States Supreme Court. The Journal of Politics, 27 (1): 133-152.

TAYLOR, Matthew. (2007), "O Judiciário e as políticas públicas no Brasil”. Dados, 50 (2): 229-257.

. (2008), Judging policy - Courts and policy reform in democratic Brazil. Stanford University Press.

TAYLOR, Matthew M. \& DA ROS, Luciano. (2008), "Os partidos dentro e fora do poder: a judicialização como resultado contingente da estratégia política”. Dados, 51 (4): 825-864.

TATE, Neal \& VALLINDER, Torbjörn, (eds.) (1995), The global expansion of judicial power. New York, New York University Press.

VALLINDER, T. (1995), "When the courts go marching in", in N. Tate e T. Vallinder, T. (orgs.). The global expansion of judicial power, New York University Press, pp. 13-26.

VERÍSSIMO, Marcos Paulo. (2008), “A Constituição de 1988, vinte anos depois: Suprema Corte e 'ativismo judicial à brasileira'”. Revista Direito GV, 4 (2): 407-440.

VIEIRA, Oscar Vilhena. (1994), O Supremo Tribunal Federal: jurisprudência política. São Paulo, Malheiros Editores. . (2008), "Supremocracia". Revista Direito $G V$, 4: 441-464 . (2010), "Quando menos é mais". O Estado de S. Paulo, Opinião, 20 abr.

VIANNA, Luiz Werneck et al. (1999). A Judicialização da política e das relaçôes sociais no Brasil. Rio de Janeiro, Iuperj/Revan.

VIANNA, Luiz Werneck; BURGOS, Marcelo Baumann \& SALLES, Paula Martins. (2007), "Dezessete anos de judicialização da política". Tempo Social, 19 (2): 39-85. 


\section{SUPREMO RELATOR: PROCESSO DECISÓRIO E MUDANÇAS NA COMPOSIÇÃO DO STF NOS GOVERNOS FHC E LULA}

\section{Fabiana Luci de Oliveira}

Palavras-chave: Supremo Tribunal Federal; Processo decisório; Perfil de ministros.

O objetivo deste artigo é investigar a dinâmica interna do processo decisório no Supremo Tribunal Federal (STF), com foco nas respostas que o tribunal dá às demandas que chegam via controle direto de constitucionalidade. Nossa hipótese é de que as respostas diferem dependendo do perfil dos ministros. Nosso interesse se dirige ao conjunto do tribunal, e não na individualidade dos ministros. Argumentamos que mudanças na composição da corte se refletem em mudanças no padrão de decisão. Elegemos para a análise um período de grande renovação na composição do STF, entre o segundo governo FHC (1999-2002) e o primeiro governo Lula (2003-2006). Mapeamos os padróes de decisão do tribunal nos casos de Ações Diretas de Inconstitucionalidade e os fatores que influenciariam essas decisões. A conclusão da pesquisa é de que a composição da Corte e o perfil dos ministros importam, mas a variável determinante no resultado da decisão é o voto do relator. Além disso, os dados permitem afirmar que, ao contrário do que aponta grande parte da literatura, o STF não é tão parcimonioso em sua atuação.

\section{SUPREME RAPPORTEUR: DECISION MAKING AND CHANGES IN THE SUPREME COURT COMPOSITION DURING FHC AND LULA GOVERNMENTS}

\section{Fabiana Luci de Oliveira}

Keywords: Supreme Court; Decisionmaking process; Justice's profile.

The purpose of this paper is to investigate the internal dynamics of decisionmaking in the Supreme Court (STF), focusing on the answers that the Court gives to the demands brought to it via direct control of constitutionality and the factors that influence these responses. Our hypothesis is that depending on the profile of the justices sitting in the Court the answer given will be different. The argument is that changes in the composition of the Court are reflected in changes in the decision-making pattern. To test this hypothesis, we have chosen a period of great renewal in the composition of the Court, between the second Cardoso government (1999-2002) and the first Lula government (2003-2006). We have mapped out the patterns of decisions in cases Direct Actions of Unconstitutionality during that period and the factors that influenced these decisions. The conclusion of this research is that the composition of court and the justices profile matter, but the most determinant variable to the outcome of the decision is the vote of the rapporteur. The data analyzed also allows to state that that unlike most studies indicate, the Supreme Court is not too parsimonious in its action.

\section{SUPRÊME RAPPORTEUR: PROCESSUS DÉCISOIR ET CHANGEMENTS DANS LA COMPOSITION DE LA COUR SUPRÈME PENDANT LES GOUVERNEMENTS FERNANDO HENRIQUE CARDOSO ET LULA}

Fabiana Luci de Oliveira

Mots-clés: Suprême Tribunal Fédéral; Processus décisoire; Profil de juges.

L'objectif de cet article est de rechercher la dynamique interne du processus décisoire au sein de la cour suprême brésilienne, le Suprême Tribunal Fédéral (STF), en ayant pour cible les réponses que le tribunal attribue aux demandes qui arrivent par la voie du contrôle direct de la constitutionalité. Notre hypothèse est que les réponses different selon le profil des juges. Notre intérêt se dirige à l'ensemble du tribunal et non pas à chaque juge individuellement. Nous soutenons que les changements dans la composition de la Cour se reflètent sur les modèles de décision. Nous avons élu pour notre analyse une période de grande rénovation dans la composition de la Cour, comprise entre le second mandat de Fernando Henrique Cardoso (1999-2002) et le premier mandat de Lula (2003-2006). Nous avons établi une carte des modèles de décision de la Cour dans les cas d'Actions Directes d'Inconstitutionnalité et les facteurs qui ont influencé ces décisions. La conclusion de la recherche est que la composition de la Cour et le profil de ses juges importe mais la variable déterminante du résultat de la décision est le vote du rapporteur. Par ailleurs, les données permettent d'affirmer qu'au contraire de ce qu'indique une grande partie de la littérature, le STF n'est pas si parcimonieux dans ses jugements. 